\title{
36-Alman ve Türk genç kız edebiyatında kahramanın kimlik arayışının aile, arkadaşlık, aşk ve cinsellik kapsamında analiziı
}

\section{Nurel CENGİZ2}

\begin{abstract}
APA: Cengiz, N. (2020). Alman ve Türk genç kız edebiyatında kahramanın kimlik arayışının aile, arkadaşlık, aşk ve cinsellik kapsamında analizi. RumeliDE Dil ve Edebiyat Araștırmaları Dergisi, (21), 608-632. DOI: 10.2900o/rumelide.835817.
\end{abstract}

Öz

Gençlik edebiyatı kimi kültürlerde gençlerle empati yapan, olaylara onların penceresinden bakan ve baktıran, yalnız olmadıklarını hissettiren bir anlayışa sahipken, başka kültürlerde el yordamıla, düşe kalka doğruyu bulmaya çalışan ve henüz kendi kararlarını vermeye yetkin olmayan bireylere sunulan bir yol haritası olarak algılanır. Genel kabule göre ilk gençlik edebiyatının 12-16 yaş grubundaki bireylere hitap etmesinden yola çıkarsak, bu yaş grubundaki gençlerin dünyanın birçok coğrafyasında benzer sorunlarla karşılaştıkları gerçeği ile karşılaşırız. Ergenlik dönemi olarak bilinen bu dönem kişilerin kimlik arayışlarının yanı sıra değişen bedenleri ile cinselliği fark ettikleri, ailedeki otoriteyi sorguladıkları, çok yoğun ve çalkantılı bir duygu yoğunluğu yaşadıkları bir süreçtir. Peki gençlik edebiyatının amacı, hedef kitlesinin karakterine uygun bir kurgu ile, dünyaya onun penceresinden bakarak, kimliğini bulmaya çalıştığı yolda arkadaşlık yapması, hatalarına göz yumması, sırdaşı olması mıdır yoksa engellerle, zorluklarla ve tuzaklarla dolu bu yolda, ona ışık tutması, düşmeden elinden tutup kaldırması ve yetişkin olduğunda yetişkin olduğunda içinde yaşadığı toplumun normlarına uyacak bir birey olabilmesine yardımcı olması için gereken bir kılavuz mudur? Her iki amaç da kültürden kültüre ve o kültürde yolunu bulmaya çalışan gençler için kabul gören varsayımlar olabilir. Bu çalışmada, Alman ve Türk gençlik edebiyatından seçilen eserlerden hareketle, aile, arkadaşlık ilişkileri, aşk, cinsellik ve toplumsal cinsiyet rollerinin ele alınışı kültürel kodların farklılığı kapsamında incelenecek ve nasıl bir amaca hizmet ettikleri tartışılacaktır.

Anahtar kelimeler: Gençlik edebiyatı, genç kız edebiyatı, ergenlik, kültürel kodlar, kimlik arayışı

\section{Analysis of the protagonist's quest for identity within the context of family, friendship, love and sexuality in German and Turkish juvenile female literature}

\begin{abstract}
Whereas, in some cultures, juvenile female literature empathizes with young adolescents by mirroring the circumstances from their perspectives and by making them feel that they are not alone, some cultures regard such literature as a roadmap that is presented to the individuals who muddle around in their own world and are not allowed to make their own decisions. In light of the fact that juvenile literature addresses individuals between twelve and sixteen years of age, it is reasonable to argue that those individuals encounter similar problems in different geographical regions. Adolescence is a process throughout which young individuals are in a quest for identity,
\end{abstract}

Bu çalısma Hacettepe Üniversitesi’nde yürütülmüs olan "Die kulturbezogene Problematik in der Adoleszenz in türkischen und deutschen Jugendromanen anhand der Werke von Ipek Ongun und Alexa Hennig von Lange" (2018) başlıklı doktora tezi çalışmasından üretilmiştir.

2 Dr. Arş. Gör., Hacettepe Üniversitesi, Edebiyat Fakültesi, Mütercim Tecümanlık Bölümü (Ankara, Türkiye), nurelyigit@gmail.com, ORCID ID: 00oo-0003-3362-2204 [Araştırma makalesi, Makale kayit tarihi: 14.11.2020-kabul tarihi: 20.12.2020; DOI: 10.29000/rumelide.835817]

Adres
Address

Istanbul Medeniyet University, Faculty of Education Sciences,

Turkish and Social Scinces Education, Turkish Language Teaching

Education, Cevizli Campus, Kartal-İstanbul /TURKEY

e-mail: editor@rumelide.com 


\begin{abstract}
become aware of their body, question family authority and go through tumultuous and intensive feelings. The question is this: does juvenile literature seek to create a fictive world in which young adolescents are befriended in their quest for identity and are tolerated with respect to their mistakes in a confidential atmosphere or does it seek to illuminate their road filled with obstacles, challenges and traps and to guide them towards social norms and rules? These differing strategies may serve as true options in different cultures where young adolescents strive to find their own way. In this context, this study seeks to analyse the cultural norms that mould family, friendship, love, sexuality and gender roles in German and Turkish systems of juvenile literature and explore how they serve different objectives in different socio-cultural contexts.
\end{abstract}

Keywords: Juvenile literature, juvenile female literature, adolescence, cultural codes, identity quest

\title{
1. Giriș
}

Edebiyat nedir sorusunun yanıtı öyle pek de kolay verilecek bir yanıt değildir. İlk başta kolay gibi görünen ancak üzerinde uzunca düşünülmesi gereken bir sorudur. Edebiyat konusunu tarih, sosyoloji, psikoloji, felsefe ve siyaset gibi diğer bilim dallarından alır ve bu bilim dallarının bir edebiyat ürününün içeriğini etkilemesi açısından edebiyatın tüm sosyal bilimlerden izler taşıdığı ifade edilebilir. Sanat nedir sorusuna antik dönemlerden itibaren, sanatın bir ayna olduğu ve dış dünyayı, dış dünyadaki hakikati yansıttığı fikri yüzyıllar boyu tartışılmış ve günümüze kadar gelmiş bir görüştür. Buradan hareketle gerçeklik nedir sorusu akıllara gelir. Bir sanat ürünü olan edebiyat nasıl bir gerçekliği yansıtır? Bu sorulara verilen cevaplar farklllıklar göstermektedir. Bu görüşler; sanatın görüngü dünyasını yansıtması, sanatın geneli ya da özü yansıtması ya da sanatın ideali yansıtması olarak ele alınmıştır (Moran, 2005:16-19-24-28). Özgül, sanat eserinin üç temel unsuru olan form, muhteva ve fonksiyon üzerinde durur (Özgül;2003). Edebiyat da bir sanat türüdür ve dolayısıyla biçim, içerik ve işlevi üzerinden değerlendirilir.

Her metnin bir işlevi bulunur. Anlatımsal metinler olarak bilinen edebi metinlerin de dönemine, ideolojisine, içeriğine göre farklı işlevleri bulunur. Bu çalışmada gençlik edebiyatı kapsamında genç kız romanları üzerinde durulacak ve edebiyatın toplum ile, dolayısıyla sosyoloji ile bağıntısı üzerinden kültür odaklı bir çözümleme yapılacaktır.

Edebiyat sosyolojisi edebi metinlerin üretimi, alımlanması, bir metnin estetiği veya edebiyat türlerinin toplumsal ve sosyokültürel koşullar kapsamında gelişmesini inceler. Edebiyat Sosyolojisinin üzerinde durduğu nokta, edebiyat ve toplumsal yaşam arasındaki ilişkinin açıklanmasıdır (Vogt, 2002:726). Erken modern çă̆lardan beri, edebiyat ve toplum arasında karşılıklı bir ilişki olduğu fikri yaygındır. 19. yüzyllda, Johan Gottfried Herder, Friedrich Schiller ve Anne Louise Germeine de Stäel gibi yazarları, edebiyatın sosyal bir görüngü olarak nasıl tanımlanabileceği ve toplum için nasıl bir işlevi olabileceği sorusu araştırmacıları meşgul etmiştir. Edebiyatın sosyal bir görüngü olarak nasıl tanımlanabileceği ve toplum için nasıl bir işlevi olabileceği sorusu, 19. yüzyllda, Johan Gottfried Herder, Friedrich Schiller ve Anne Louise Germeine de Stäel gibi yazarları meşgul etmiştir. Bu yazarlar edebiyatı toplumsal bağlamı içerisinde ele almışlardır. Örneğin, natüralizm çevre kuramı (Milieutheorie) bağlamında, edebiyat ve toplum arasında koşullu bir ilişki olduğu varsayılmıştır (Köppe/Winko, 2013: 149). Toplum ve toplumun düşünsel ürünü olan edebiyat arasındaki ilk kapsamlı teori Karl Marx tarafından geliştirilmiştir. Marx, Friedrich Engels ile geliştirdiği Toplumsal Gerçeklik Teorisinde Hegel idealizmine ve estetiğine eleştirel yaklaşmış ve entelektüel üretimin, maddi

\footnotetext{
Adres $\mid$ Address

İstanbul Medeniyet Üniversitesi, Eğitim Bilimleri Fakültesi, Türkçe İstanbul Medeniyet University, Faculty of Education Sciences, ve Sosyal Bilimler Eğitimi Bölümü, Türkce Eğitimi ABD Cevizli Turkish and Social Scinces Education, Turkish Language Teaching Kampüsü, Kartal-İstanbul/TÜRKIYE $\quad$ Education, Cevizli Campus, Kartal-İstanbul /TURKEY e-posta: editor@rumelide.com 1 e-mail: editor@rumelide.com
} 
Analysis of the protagonist's quest for identity within the context of family, friendship, love and sexuality in German and Turkish juvenile female literature / N. Cengiz. (pp. 608-632)

yaşam koşullarından bağımsız ortaya çıkamayacağını iddia etmiştir. Edebiyatın, toplumsal gerçekliği yansıttığını ve burjuva-kapitalist toplumun çelişkilerini ve insanın kendine yabancılaşmasını ifade etmesi bağlamında ölçülebilir olduğunu öne sürmüştür (Köppe/Winko, 2013: 150). Marx ve Engels, ortaya attıkları Marksist Kuram ile sanatı, dolayısıyla edebiyatı da ekonomik sisteme bağlamışlar ve aradaki bağın niteliği üzerinde durmuşlardır. Moran'ın da ifade ettiği gibi, Marksizm ekonomik teori üzerine oturtulmuş bir tarih felsefesidir ve tarihin gelişmesinin birtakım kanunlara göre cereyan ettiğini iddia eder. Söz konusu kanunlar tarihi maddecilik bağlamında açıklanır. Tarihi maddeciliğe göre bir toplumun üstyapısı, yani her türlü kültürel faaliyeti, ahlaki, hukuki, dini görüşleri toplumun ekonomiye bağlı alt yapısına bağlıdır. Dolayısıyla, bir toplumun üstyapısını anlayabilmek için o toplumun altyapısını bilmek gerekir. Toplum tarihinde başlıca görülen aşamaları: İlkel toplumlar, kölelik üzerine kurulmuş toplumlar, feodalizm, kapitalizm, sosyalizm ve nihayet komünizm olarak tanımlar. Marx'in teorisine göre toplumun eninde sonunda sosyalizme ve nihayet komünizme varacağını önceden görmek mümkündür (2005:35).

Günümüzde Marksist varsayımlar artık saf haliyle temsil edilmiyor ancak temel Marx'ın ortaya attı̆̆ı bu temel düşünce biçimi Max Weber, Georg Simmel gibi isimlere itki olarak hizmet etmiştir. Marx'ın teorisi üzerine eklemeler yaparak günümüze taşıyan ve daha işlevsel hale getiren isimler arasında özellikle Georg Lukács, Theodor Adorno, Fredric Jameson, Terry Eagleton, Theodor W.Adorno ve Pierre Bourdieu sayılabilir (Vogt, 2008: 726).

$\mathrm{Bu}$ çalışmanın temelini oluşturacak kuramsal artalanda kültür ve edebiyat sosyolojisi alanında geçerliliğini ve önemini hala sürdüren Pierre Bourdieu'nun görüşlerine başvurulacaktır. Bourdieu geliştirdiği ve ekonomik sermayeden tamamen bağımsız ele aldığı simgesel sermaye teorisi ile edebiyat sosyolojisine yeni bir soluk getirir. Ona göre, bir bireyin bir sosyal sınıfa tasnifi ve kişinin toplumsal etkilerinin değerlendirilmesi modern toplumlarda para, üretim araçları veya mülkiyet gibi salt ekonomik sermayenin dağılımı ile değil, aynı zamanda akrabalık, ikili ilişkiler gibi toplumsal, eğitim, unvan, dil becerileri gibi kültürel ve kıyafet, beden dili, tutum ve davranış gibi simgesel sermayenin dağılımı ile de yakından ilişkilidir. Birey bu sermayeleri elde etmek ve biriktirmek için mücadele eder. Bu bağlamda simgesel sermaye, diğer sermaye birikimlerinin varlı̆̆ını dışa vurma görevini üstlenir (Vogt, 2008: 728). Bourdieu'nun teorisi her kültürün kendi iç dinamiklerine göre şekillenebilir. Her kültürde farklı sermaye birikimleri farklı bir öneme ve değere karşllı gelebilir. Malzemesini toplumdan alan edebiyat ise bizlere farklı kültürlerin değerlerini kurgusal bir düzlemde alımlama firsatı sunar.

Moran, edebiyat eserlerini inceleyen bir eleştirmenin, bir yargı ortaya koymaktan ziyade, eseri açıklamak, yorumlamak suretiyle anlamını kavramaya yol açan ve eserin özelliklerini aydınlatan kişi olması gerektiğini belirtir. Bu açıdan ele alındığında, iyi bir eleştirmen eserin öğelerini daha iyi kavratabilir, bu öğelerin meydana getirdiği yapıyı sezdirir, kimi toplum sorunlarına dikkati çekebilir (Moran,1994: 301). Tüm bu tartışmalar ışığında, edebiyat sosyolojisi, edebiyat ve toplum arasındaki karşılıklı ilişkiyi inceleyen bir disiplin olarak önem taşımaktadır. Edebiyat sosyolojisinin temel savlarından biri, edebiyatın ve edebi metinlerin, toplumsal ve kültürel bağlamı içerisinde değerlendirilmesi gerektiğidir. Edebiyat ve toplum arasındaki ilişkinin karşılıklılığı mutlaka vurgulanmalıdır (Kırtıl, 2012). Sadece içerik olarak değil, işlevsel açısından da kültürden kültüre farklılıklar görülebilir. Edebiyatın işlevi kuşkusuz dönemin şartları gereği farklılık gösterebilir. Aydınlanma döneminde edebiyatın amacı öğretmek, eğitmek ve sorgulatmak iken, bu amaç ilerleyen edebi dönemlerde sürekli bir değişime uğramıştır.

Adres 
“Edebiyat nedir?” “Amacı, işlevi nedir?” sorularından hareketle edebiyat ve toplum arasındaki ilişkinin önemine değindikten sonra, kendi içinde birtakım kuralları olan gençlik edebiyatının bir alt türü olan genç kız edebiyatının içinde gizlenen dünya görüşünü açığa çıkarmayı çalışalım.

\section{Almanya'da genç kız edebiyatı}

Genç kız edebiyatı aynı zamanda ergen edebiyatı dizininde de yer almaktadır ancak ülkemizde ne genç kız edebiyatı ne de ergen edebiyatı olarak kabul görmüş edebiyat türleri bulunmaktadır. Her ikisi de çocuk ve gençlik edebiyatının içinde yer almakta ve kabul görmektedir.

Neydim, Dahrendorftan yola çıkarak, genç kız edebiyatının en temel ve basite indirgenmiş tanımının, okuyucu kitlesi yalnızca genç kızlar olan bir edebiyat türü olması ve en önemli özelliğinin, okuyucu kitlesinin genç kızlar olmasının dışında, kitap kahramanlarının da genç kızlar/kadınlar olması; böylece, özellikle genç kızların duygu, düşünce ve yaşantılarını aktarmasıdır şeklinde tanımlar (2007:473). Bu bağlamda genç kız edebiyatından hedef kitlesi ergenlik çağındaki genç kızlar olan ve özellikle belirtilen dönemdeki sorunları ve konuları içeren bir yazın türünden bahsedebiliriz.

Genel olarak ele alındığında Almanya'da genç kız edebiyatı geleneğinin iki farklı bakış açısını izlemiş olduğu görülür. 18. ve 19. yüzyllardan 1970'lere kadar olan zaman diliminde etik değerler bağlamında eğitsel bir kurgunun amaç edinilmesi söz konusuyken 1970’lerden sonra daha gerçekçi ve kahramanların psikolojik çözümlerinin de işlendiği bir kurgunun öncelik kazandığını söylenebilir.

Genç kız edebiyatı, genç kızlar için yazılmış ergenlik romanının bir biçimi olarak kabul edilir. Almanya'da genç kız romanları Aydınlanma döneminde geliştirilmiştir. Burada asıl amaç, genç kızları eş ve anne olarak hayata hazırlamaktır. Bu okumalara dayanarak, kızlar toplum tarafından kabul edilen gelenek ve sosyal beklentileri tanımalı ve aynı zamanda, bir evi çekip çevirmeyi de öğrenmelilerdi. Aydınlanma döneminin başlıca çağrısı olan aklını kullan ve sorgula kavramları ışığında kadınların özgürleşme özlemlerini ortadan kaldırmayı ve kadınlara eş ve anne olarak görevlerini hatırlatmayı amaçlayan bir çaba dikkat çekmektedir. Devam eden dönemlerde bu anlayışın uzun süre geçerliliğini koruduğunu ifade etmek mümkündür. Toplumsal olarak yerleşik normlar içinde büyümek ve bunlara sahip çıkmak anlayışı ile ele alınmış genç kız romanları "kızarmış balık edebiyatı" anlamına gelen "Backfisch Literatur" olarak ifade edilmiştir. Bu terim Almanya'da eski zamanlarda ergenlik çağındaki kızlar için kullanılmaktaydı ve bu kızlara yönelik kitaplara da adını vermiştir (Cengiz, 2018:98).

Dönemin gereklilikleri kapsamında genç kız romanlarının amacı ve işlevi sürekli bir değişime uğramıştır. Şöyle ki, 1. ve 2. Dünya Savaşları sırasında kaleme alınan eserlerde savaş koşullarında ayakta durabilecek ve rol model olarak işlev gören kadın imgesi psikolojik ve fizyolojik donanımlara sahiptir. Güçlüdür, dayanıklı ve dirayetlidir. Bu açıdan ilgili dönem eserlerinde kadın motifi dişilik özelliklerinden uzaklaşmıştır ancak 1950-1970'li yıllar arasında kurulan yeni sistemin gereklilikleri kapsamında kadınları tekrar evlere bağlayan, anne ve eş rollerinin vurgulandığı eserler kaleme alınmıştır (Wild 2008:379). 1960'lı yılların başlarında geleneksel aile modeli genç kız edebiyatında varlığını hala sürdürmekle birlikte, kadınların iş hayatlarında daha aktif yer almaları ile geleneksellikten yavaş yavaş uzaklaşmaların da başladığı dönemlerdir (Wild 2008:380). 68 ruhunun da etkisiyle 1970'li yıllarda genç kız edebiyatı tüm zincirlerinden kopmayı başarır. Cinselliğin özgürce yaşandığı konuların, geleneksel aile ve kadın modelinin yerine özgür ve bağımsız kadın modelinin öne çlktığı ve genç kızların kendi kaderlerini tayin edebildikleri içeriklerin yer aldığı görülür (Wild

Adres

İstanbul Medeniyet Üniversitesi, Eğitim Bilimleri Fakültesi, Türkçe ve Sosyal Bilimler Eğitimi Bölümü, Türkçe Eğitimi ABD Cevizli Kampüsü, Kartal-İstanbul/TÜRKIYE e-posta: editor@rumelide.com 
Analysis of the protagonist's quest for identity within the context of family, friendship, love and sexuality in German and Turkish juvenile female literature / N. Cengiz. (pp. 608-632)

2008:381-383). 1980'li yıllara gelindiğinde ise kahramanların psikolojilerinin de ele alındığı, depresyon ve yeme bozuklukları gibi konuların işlendiği psikolojik genç kız romanları ile karşlaşmaktayız.

Alman genç kız edebiyatında en çok dikkat çeken unsur, kahramanın genç bir kadın olarak kabul edilmesidir. Bu genç kadın kendi kimlik arayışını düşe kalka ve hatalar yaparak tamamlamaya çalışır. Kahramanlara hata yapma özgürlüğü tanınır. Cinsellik çok geniş bir perseptifte ele alınabilir ve tabular söz konusu değildir (Wild 2008:384-385). 1980'lerden itibaren postmodern bir genç kız edebiyatından bahsedilir. Burada kurguyla amaçlanan kahramanın toplum tarafından kabul görmüş geleneksel bir kimlik arayışı değildir, asıl önemli olan kahramanın deneme yanılma yoluyla, asla son bulmayan bir arayışla, mutlak doğrusu olmayan, içinde tezatlar da taşıyan alt kimlikleri birleştirerek bir Patch-Work kimliği oluşturmasıdır.

Bu çalışmada genç kız edebiyatı aynı zamanda bir ergenlik romanı olarak modern gençlik romanının bir tezahürü veya alt türü olarak ele alınacaktır. Ergenlik romanları 12-25 yaş arası kabul edilen ergenlik dönemiyle sınırlı olmayabilir. Eserlerde anlatım, ergenlik öncesinden başlayarak ergenlik sonrasına kadar uzayabilir. Odak noktasını kahramanların ergenlik dönemindeki büyüme sorunları ve kimlik arayışları oluşturur ve bu bağlamdaki varoluşsal bunalımları ve kimlik krizleri motifleri üzerinden ele alınır. Bireyleşme ve sosyal entegrasyon arasındaki ilişki de bu okumalarda bir sorun olarak vurgulanabilir (Wild 2008:362). Kaulen ve Gansel'e göre ergenlik dönemi romanı klasik gençlik yazınından aşağıdaki özellikler açısından farklılık arz eder:

- Genellikle bir veya daha fazla gencin ergenlik dönemi anlatılır. Eskiden çoğunlukla erkek bir kahramanın tasvir edilmesi geleneği yaygın iken günümüzde romanlarda kadın kahramanlara daha fazla yer verilmeye başlanmıştır. Ergenlik romanının genç kahramanları yaklaşık 11 ila 12 yaşları ile yirmili yaşların ortalarına veya sonlarına kadar uzanabilir.

- Ergenlik dönemi istikrarsız bir kimlik ve anlam arayışı süreci olarak ele alınır. Olay örgüsü tespit edilmiş birkaç problem alanı odağında kriz deneyimleri veya kabul görme çabaları üzerinden oluşturulur. Bu problem alanları için; ilk cinsel deneyimler, aileden ayrılma, ebeveynlerin boşanması, kişinin kendi değer sisteminin ve sosyal ilişkilerinin gelişimi ve toplum tarafindan kendisine dayatılan sosyal rollerin kabul veya red edilmesi olarak ifade edilebilir.

- Kaulen, Ergenlik Romanlarında karakterin kimliğini bulma sürecinin genellikle olumlu ve nihai bir çözüm olarak vuku bulmamasının karakteristik bir özellik olduğunu ifade eder. Karakterin eylemlerinin başarısızlıkla sonuçlanması ancak açık bir son ile telafi edilebilir bir süreç olarak ele alınması anlayışı hakimdir.

- Ergenlik romanı, sorun odaklı gerçekçi gençlik yazınlarında ele alınan tipik karakterlerle ve örnek olay örgüsü üzerinden kurgulanmaz. Ergenlik romanlarında karakter, modern roman anlayışındaki radikal özne anlayışına uygun olarak bireysel ve eşsiz birer varlık olarak ele alınır. Bu bağlamda odak noktası kahramanların psikolojik iç dünyalarıdır. Krizleri ve kafa karışıklıkları nedeniyle bunlar okuyucuya çelişkili ve karmaşı bireyler olarak görünürler. Oldukça karmaşık iç dünyalara sahip kahramanları araştırmak için bir takım modern psikolojik anlatım teknikleri kullanılmaktadır, bunlar; birinci şahıs anlatıcı, iç monologlar, rüya sekansları ve bilinçaltının sembollerle kodlanarak dışavurumudur (Kaulen 1994:7).

Adres

İstanbul Medeniyet Üniversitesi, Eğitim Bilimleri Fakültesi, Türkçe ve Sosyal Bilimler Eğitimi Bölümü, Türkce Eğitimi ABD Cevizli Kampüsü, Kartal-İstanbul/TÜRKIYE e-posta: editor@rumelide.com 
Modern ya da postmodern ergenlik romanlarında, kahramanların ergenliği kendilerini sınamak için bir firsat olarak gördükleri sıklıkla gözlemlenebilir. Bu süreç keyif ve zevk veren bir faaliyet olarak açık bir şekilde yaşanır. Hayatın kesintisiz bir parti olarak görüldüğü bir dönemi ifade eder (Gansel 1999:141). Almanya'da, nispeten yeni bir terim olarak kabul edilen ergenlik romanının kökeni 18. yüzylla kadar uzanmaktadır. Markus Wagner'e göre, Goethe'nin "Genç Werther'in Aclları” ve Karl Phillip Moritz’in “Anton Reiser” eserleri, günümüz ergen romanının ilk örnekleridir. (Wagner 2005: 4) Genel olarak Gençlik Edebiyatının geçmişine baktığımızda, özellikle 18. yüzyıldan itibaren, öncelikli hedefi eğitim olan bir tür görümekteyiz. Edebiyat, ergenlik dönemindeki gençlere bu zorlu geçiş döneminin üstesinden gelmek için yol gösterici bir araç olarak hizmet etmekte ve bireyin toplumsal düzene başarılı bir entegrasyon sağlayabilmesi için bir çözüm modeli sunmaktadır (Kaulen 1999:8). Burada oldukça önemli olan "toplumsal düzene başarılı bir entegrasyon sağlayabilme" hedefi göze çarpmaktadır ve bu çalışmanın kilit noktalarından birini teşkil etmektedir.

Almanya'da edebi bir tür olarak ergen edebiyatından ancak 1980’li yllardan itibaren söz etmek mümkündür. Ergen edebiyatının Angloamerikan "adolescent novel" kavramından esinlenerek Almanya'da da etkili olmaya başladı̆̆ı görülmektedir ve ABD dışında İskandinav ülkelerinin edebiyatlarında da etkili olduğu gözlemlenmektedir (Wild, 2008: 353) 68 Hareketinden sonra geleneksel kadın anlgısının değişmesiyle birlikte gençlik ve ergen edebiyatında da kadın ve genç kızlara yönelik toplumsal dayatlmarın ve yine toplumsal olarak genel kabul görmüş ritüellerin sorgulandığı bir yaklaşım görülmektedir (Wild, 2008: 347). Geçmişi her ne kadar didaktik bir zemine oturmuş olsa da, günümüz koşullarında eğitici amaç güden bir gençlik edebiyatı güncellliğini ve işlevini ne kadar sürdürebilir ve günümüz genç kızlarını böylesi didaktik bir yaklaşımla okur olarak kazanmak ne kadar mümkündür sorusu akıllara gelmektedir.

\subsection{Türkiye'de genç kız edebiyatı}

Türkiye'de genç kız edebiyatının çıkış noktası Almanya ile benzerlikler göstermektedir. Almanya'dakinden 100 yll sonra, Türkiye'de yüzeyde romantik aşk hikayelerini ele alan, ancak önceden belirlenmiş toplumsal cinsiyet rollerini zorlayan genç kız kitapları görülmektedir. Ancak çıkış noktasındaki paralelliğe tezat olarak Türkiye'de genç kız edebiyatının zaman içerisinde dönemin ruhu ile paralel bir dönüşüm göstermediğini görmekteyiz.

Özyer 1987 yılında kaleme aldığı makalesinde Türkiye'de gençlik edebiyatı ile ilgili gelişmelerin Almanya ile hiçbir şekilde parallelik göstermediğini ifade eder. Ülkemizde, gençlik edebiyatının kavramsal ve içerik olarak tam açıklığa kavuşturulmadığını ve ayrıca edebiyat biliminde yeri olan özel bir tür olmadığını ifade eder. Hatta ülkemizdeki bazı edebiyat bilimcilerin, edebiyatta çocuk veya genç ayrımının olmayacağını, edebiyatın yaşlara göre ayrılamayacığının tezini savunduğunu belirtir (1987:257). Neydim ise Gençlik Edebiyatının durumunu şu sözlerle ifade eder:

Gençlik edebiyatının ülkemizde tanımlama sorunuyla karşılaștığını söylemek pek olanaklı değildir, çünkü böyle bir tanım sorunu ne eğitim sisteminde ne de edebiyat alanında gerçek anlamıyla ele alınmıştır. Yukarıdaki tanımlamaları göz önüne aldığımızda, gençlik edebiyatının varlığı konusunda kuşkuya bile düşebiliriz. Son yıllara kadar gençlik edebiyatı olarak tanımlanan kitapların çoğunlukla yetişkinler tarafindan seçilmiş veya derlenmiş kitaplar olduğunu söylemek ise yanlış olmaz. (Neydim, 2014:695)

Avrupa ülkelerinin aksine Türkiye'de 19. yüzyılda hala gençlere yönelik bir edebiyatın olmadığını, sadece gençlerin tartışıldığı bir edebiyatın olduğunu görmekteyiz. Özyer bu durumu Türkiye'de Cumhuriyet öncesi dönemlerde eğitim sisteminin din ağırlıklı olması nedeniyle gençlik edebiyatının bu

Adres

İstanbul Medeniyet Üniversitesi, Eğitim Bilimleri Fakültesi, Türkçe ve Sosyal Bilimler Eğitimi Bölümü, Türkçe Eğitimi ABD Cevizli Kampüsü, Kartal-İstanbul/TÜRKIYY e-posta: editor@rumelide.com 
dönemlerde kendine uygun bir temel bulamaması şeklinde açıklamaktadır (1987:257). Edebi bir tür olarak roman ancak 19.yüyılda Türkiye'de gelişmeye başlamıştır. 20.yüzyılın başlarında Halide Edip Adıvar'ın Handan ve Reşat Nuri Güntekin’in Çalıkuşu romanlarının örnek olarak ifade edilebildiği gençlik romanlarında modernlik ve gelenekler arasında sıkışmış genç kahramanların konu edinildiği eserler dikkat çekmektedir (Neydim, 2005:27). 1960'lı yllardaki öğrenci olaylarından sonra özellikle politik gençlik romanlarının öne çıktığını görmekteyiz (Özyer,1987:260). Genç kız romanlarında genel olarak belirgin bir tutuculuk ve dünya görüşlerinde durağanlık göze çarpmaktadır. Her ne kadar eski ve yeni romanlar ile karşılaştırıldığında yüzeysel bir gelişim veya değişim görülse dahi, özünde işlenen dünya görüşlerinde bir değişme olmadığı gözlenir (Neydim, 2014:697). Tanzimat döneminden (18381876) Batılılaşma Hareketlerine kadar olan sürede üretilen erlerde bir yandan geleneklere tutunan, diğer yandan da Batı'nın etkisi altında yeni bir kimlik oluşturmaya çalışan genç kız figürleri ortaya çıkmaktadır. Kurtuluş Savaşı sırasında modern ama aynı zamanda geleneğe bağlı kadının askeri, siyasi ve ataerkil tutumları görülebilmekteyken. 1970 'lerde, öğrenci hareketlerinin etkisiyle politik düşünen kahramanlar görülmektedir.

Bununla birlikte, kızlara yönelik eğitici ve didaktik edebiyatın bugün hala geçerliliğini koruduğunu belirtmek üzücüdür. Neydim'e göre, ideal-tipik karakterler ve kahramanlar bugünün Türkiye'sinde hala kahraman olarak karşımıza çıkmaktadır. Bu kahramanlar didaktik amaçlara hizmet ederler, çünkü normlara uygun davranırlar ve kimlik gelişimleri toplumsal olarak belirlenmiş değerlere uygun olarak tamamlanırken bu süreci de fazla kafa karışıklığı olmadan geçirirler. Bu eserlerdeki genç kız figürleri toplumsal gerekliliklerin ışı̆̆ında eğitilmesi gereken varlıklar olarak ele alınırlar (Neydim 2005:20). Buraya kadar görmekteyiz ki, Alman ve Türk genç kız edebiyatının amaçları ve işlevleri açısından birbirinden çok farlı bir seyir izlemektedir. Günümüz Türkiye'sinde, Almanya'nın 100 yıl öncesi tutumu süregelmektedir ancak dünyada kültürlerin bu denli etkileşim halinde olduğu ve içinde bulunduğumuz zamanda Türk genç kızının bir Alman genç kızından çok farklı bir dünyasının olmadığı, duyguları, sorunları, fantezilerinin ve kimlik arayışının çok farklı olmadığı fikri pek de yadsınacak bir düşünce değildir. Küreselleşen dünyamızda, farklı kültürlerin etkisinde en çok kalan grubun gençler olduğu açıktır. Gerek kitle iletişim araçları gerek gündemin olmazsa olmazı kabul edilen sosyal medya ile farklı kültürlerin etkisi çekirdek aileleri etkisi altına almıştır. Böyle bir ortamda, hala geleneksel toplumsal normların birer yol gösterici olarak genç kız edebiyatında varlığını koruyabilmesi ve genç kızlar tarafından sevilerek okunması üzerinde düşünülmesi gereken bir husustur.

\section{Kuramsal çerçeve}

Bu çalışmada genç kız edebiyatının ergenlik dönemindeki Türk ve Alman kahramanlarına nasıl birer misyon yüklendiği araştırılacaktır. Bu bağlamda, Alman edebiyatından Alexa Hennig von Lange'nin Lelle serisi olarak da kabul edilen şu eserleri incelenmiştir:

- $\quad$ Ich habe einfach Glück- 2001

- $\quad$ Erste Liebe- 2004

- $\quad$ Leute, Ich fühle mich leicht- 2008

- $\quad$ Leute, mein Herz glüht- 2009

- $\quad$ Leute, die Liebe schockt- 2009

- $\quad$ Leute, das Leben ist wild- 2010 
Bu eserlerin seçiminde etkili olan başlıca faktör, von Hennig’in 2002 yllında bu serinin ilk kitabı olan "Ich habe einfach Glück" romanılla Alman gençlik edebiyatı ödülü olan "Deutscher Jugendliteraturpreis” ödülünü kazanmış olmasıdır.

Türk edebiyatından ise en çok satanlar arasında yer alan ve her dönem geniş bir okur kitlesi olan İpek Ongun’un “Bir Genç Kızın Gizli Defteri” serisinin ilk 6 kitabı seçilmiştir. Bunlar sırasıyla şunlardır;

- $\quad$ Bir Genç Kızın Gizli Defteri- 1990

- $\quad$ Bir Genç Kızın Gizli Defteri- Arkadaşlar Arasında- 1997

- $\quad$ Bir Genç Kızın Gizli Defteri- Kendi Ayakları Üstünde- 1998

- $\quad$ Bir Genç Kızın Gizli Defteri- Adım Adım Hayata- 2000

- $\quad$ Bir Genç Kızın Gizli Defteri- İşte Hayat- 2005

- Bir Genç Kızın Gizli Defteri- Şimdi Düğün Zamanı- 2012

$\mathrm{Bu}$ eserlerin seçilmelerindeki bir başka neden ise birbirlerine yakın zamanlarda çıkmış olmaları ve 1990 ve 200o'lerin başlarındaki zaman dilimini içermeleridir. Aynı zamanda bir genç kızın belirli bir süreçteki gelişimini birkaç kitap boyunca takip edebilme imkânı sağlamış olmalarıdır.

İncelenen eserlerde öncelikli olarak yanıt aranan sorular şunlardır;

- Toplumsal düzene başarılı bir entegrasyon sağlayabilme hedefi bu eserlede ne kadar öncelikli bir amaç olmuştur?

- Eserler kahramanlarının hayatları ve seçimleri üzerinden kimlik arayışı içinde bulunan okurlarına birer yol gösterici olarak mı hizmet etmektedir, yoksa onlarla empati kuran ve dünyaya onların penceresinden bakan birer arkadaş olarak mı yaklaşmaktadırlar?

- Eserlerdeki kahramanlar evrensel olarak kabul edilen ergenlik dönemi özelliklerini yaşarken, içinde bulundukları kültür, onların seçimlerini ve yaşamlarını etkiler mi, etkiliyorsa, hangi bağlamlarda etkiler?

- Kahramanların kimlik arayışında aile, arkadaşlık, aşk, cinsellik ve cinsiyet rolleri kültür bağlamında nasıl ele alınmıştır?

Yukarıda ifade edilen sorular kültür odaklı bir yaklaşımla ele alınacaktır.

Hollandalı antropolog Geert Hofstede'nin geliştirmiş olduğu Kültürel Boyutlar Kuramının çıkış noktası, farklı toplumlarda insanların benzer sorunlarla farklı çözümler üretmesine dayanır. Mutluluk, üzüntü, kırgınlık, tedirginlik vb. duygular evrensel ve tüm insanlara özgü duygular olmakla birlikte, farklı toplumlarda insanlar bu duyguları ifade etme, özgürce yaşama veya bastırma gibi konularda da farklılıklar göstermektedir. Dünya üzerinde 5o'den fazla ülkede yapmış olduğu çalışmalar ve anketler ile ülkelerin aşağıda belirtilen kültürel boyutlarda hangi değerlerde olduklarını saptamaya çalışmış ve bu davranışların temellerini açıklamaya çalışmıştır.

Hofstede'nin Kültürel Boyutlar Teorisi 6 temel boyuttan oluşmaktadır. Bunlar şu şekilde ifade edilmektedir.

- Güç Mesafesi

\footnotetext{
Adres $\mid$ Address

İstanbul Medeniyet Üniversitesi, Eğitim Bilimleri Fakültesi, Türkçe İstanbul Medeniyet University, Faculty of Education Sciences, ve Sosyal Bilimler Eğitimi Bölümü, Türkçe Eğitimi ABD Cevizli Turkish and Social Scinces Education, Turkish Language Teaching Kampüsü, Kartal-İstanbul/TÜRKIYE $\quad$ Education, Cevizli Campus, Kartal-İstanbul /TURKEY e-posta: editor@rumelide.com 1 e-mail: editor@rumelide.com
} 
Analysis of the protagonist's quest for identity within the context of family, friendship, love and sexuality in German and Turkish juvenile female literature / N. Cengiz. (pp. 608-632)

- Bireysellik /Kolektivizm (Ortaklaşa Davranışçllı)

- Erillik / Dişilik

- Belirsizlikten Sakınma

- Uzun Dönemli Yönelim - Kısa Dönemli Yönelim

- Serbestlik / Kısıtlama

Bu bağlamda Geert Hofstede'nin Kültürel Boyutlar Teorisinde yer alan güç mesafesi, bireycilik veya kolektivizm ve serbestlik/kısıtlama boyutlarından yola çıkılarak kültürel bir sınıflandırma yapılacaktır. Belirsizlikten sakınma ve uzun dönemli yönelim, kısa dönemli yönelim ve erillik / dişilik boyutları incelemeye dahil edilmeyecektir.

Bu boyutları kısaca tanımlayalım. Güç mesafesi özellikle hiyerarşik sistem ve aile içi güç dağılımları ve otorite figürleri kapsamında ele alınacaktır. Hofstede' ye göre güç mesafesi yüksek toplumlarda küçüklerden büyüklere karşı saygılı olmaları beklenir ve itaat önemli bir beklentidir. Büyüklerin küçüklerine karşı zaman zaman aşırıya kaçacak bir korumacılık ile bağlı olmaları göze çarpan bir özelliktir. Kişiler küçük yaştan itibaren "saygılı davranış" kalıpları öğrenilirler ve büyüklere, statü olarak daha yüksektekilere (baba, anne, aile büyükleri, yaşça büyükler, öğretmen, amir) karşı daha edilgen bir duruş toplumsal olarak kabul edilen davranış biçimidir. $\mathrm{Bu}$ aralığın düşük olduğu toplumlarda bireyler toplum içerisinde eşit bir güç seviyesine sahiptir ve eğitim, gelir, işyerindeki pozisyon gibi etkenler ile daha üst bir statüye erişmek mümkündür (Hofstede, 2010:63-91). Türk toplumu yüksek güç mesafesinde yer alırken Alman toplumu düşük güç mesafesi endeksinde yer alır. 3

Bir toplumdaki bireylerin kendilerini birer birey olarak mı gördükleri yoksa bir grubun üyesi olarak mı davranışlarını kontrol altında tuttuklarını Hofstede bireycilik /kolektivizm boyutu ile ele almaktadır. Bireysellik kavramının yüksek olduğu toplumlarda, bireysel menfaat ve hedeflerin toplumsal menfaat ve hedeflerden önde geldiği söylenebilir. Bu kültürlerde farklı görüşlerin ortaya konması, açıkça tartışılması gerçeğe yaklaşabilmek için yararlı görülür. Kolektivist yapıya sahip toplumlarda grup içi bağlar güçlüdür ve aile kavramı daha geniş kapsamlıdır. "Biz" odaklı kolektivist toplumlarda grubun dayattığı sorumlulukların yerine getirilmesi gerekli iken odağı "Ben” olan bireyselci toplumlarda birey kendi belirlediği sorumlulukları ya da görevleri yerine getirir ve çekirdek aile olarak tanımlanan aile kavramı yaygındır (Hofstede, 2010:124-140). Bu boyutta Türk toplumu daha ziyade kolektivist ölçütte yer alırken, Alman toplumu daha bireyselci yönelimde görülmektedir.

Üçüncü boyut olan erillik veya dişilik ile Hofstede bir toplumda cinsiyete dayalı rollerin ne kadar belirgin olarak birbirinden ayrıldığını araştırır.

Eril kültürlerde cinsiyet rollerinin keskin bir şekilde belirlenmiş olduğu gözlemlenir. Bu kültürlerde erkeklerden kararlı, sert, maddi yönelimli olmaları beklenirken, kadınların alçakgönüllü, duygusal, duyarlı ve narin olmaları tasvip edilir. Eril kültürlerde hem genç kızlar hem delikanlılar hırslı ve rekabet yönelimli olmayı öğrenirler. Çocuklar «güçlü olana» hayranlık duyarlar, okulda öğrenciler kendilerini gösterme çabasındadır. Dişil kültürlerde ise cinsiyete dayalı rollerin birbiriyle değiştiği hem kadınların hem de erkeklerin alçakgönüllü, hassas, narin vs. oldukları gözlemlenir. Bu kültürlerde her iki cinsiyet de alçakgönüllü, duyarlı vs. olmayı öğrenir. Çocuklara zayıftan ve ezilenden yana olmayı öğretirler. Öğrenciler çalışkan ve gayretli oldukları fikrini uyandırmaya çalışırlar. Terbiye, alçak gönüllülük, dayanışma öne çıkar. Sosyal bağlantılar, yardımlaşma iş yerinde ideal görülür (Hofstede,

3 https://www.hofstede-insights.com/product/compare-countries/

Adres

İstanbul Medeniyet Üniversitesi, Eğitim Bilimleri Fakültesi, Türkce ve Sosyal Bilimler Eğitimi Bölümü, Türkce Eğitimi ABD Cevizli Kampüsü, Kartal-İstanbul/TÜRKIYE e-posta: editor@rumelide.com
Address

Istanbul Medeniyet University, Faculty of Education Sciences,

Turkish and Social Scinces Education, Turkish Language Teaching

Education, Cevizli Campus, Kartal-İstanbul /TURKEY

e-mail: editor@rumelide.com 
2010:154-169). Türk toplumu daha dişil özellikler gösterirken Alman toplumu ise daha eril bir yapıya sahiptir.

Serbestlik / kısıtlama boyutu aslında mutluluğun ölçüsü hakkında bilgi verir. Serbestlik ve kısıtlama bir toplumun üyelerinin heveslerini, kişisel istek ve arzularını ne ölçüde bastırdığı veya özgürce yaşadığı ile ilgilidir. Bireylerin boş vakitlerinin ne derecede keyif odaklı olduğu, cinselliğin ne derece serbestçe yaşandığı, sigara, alkol gibi keyif verici maddelerin ne ölçüde gündelik hayatta yer aldığı ile ölçülür.

Serbest topluluklar göreceli olarak isteklerini ve heveslerini yerine getirmekte kendilerini özgür bırakmışlardır ve hayattan zevk almak veya eğlenmek gibi faaliyetleri birer doğal insan davranışı olarak ele alırlar. Buna karşı olarak kısıtlama halindeki topluluklarda ise insani zevklerin ve heveslerin katı toplumsal kurallar tarafından kontrol edildiği görülür. Kısıtlayıcı toplumlarda otokontrol önem kazanır ve bireyler sosyal normlar doğrultusunda kişisel istek ve arzularını baskılamak zorunda kalırlar. Ahlak, disiplin ve otokontrol bu toplumlarda önceliklidir (Hofstede, 2010:300-306). Türk toplumu öz disiplin uygulamayı öğrenmek zorunda olan kısıtlayıcı toplum kategorisinde yer alır, Alman toplumu ise diğer uçta yer alan serbest toplum boyutunda bulunur.

Belirtilen eserler ifade edilen kültürel boyutlar kapsamında incelenecek ve elde edilen bulgular kapsamında değerlendirilecektir.

\section{Eserlerin kısa özetleri}

\subsection{Türk edebiyatından seçilen eserlerin özeti}

Ortaokul öğrencisi olan 15 yaşındaki Serra Noyan akademisyen babası ve bankacı olan annesi ile Ankara'da yaşamaktadır. Orta üst sosyoekonomik bir sınıfa mensup oldukları söylenebilir. Ebeveynlerinin entelektüel birikimlerin yüksek olduğu anlaşlmaktadır ve mesleki gelişimleri toplumda kabul gören statülerdir. Serra hikâyenin başında biraz kilolu, pek güzel sayılmayan, sivilceli ve özgüveni düşük bir genç kız iken ilerleyen süreçte dış görünüşüyle paralel olarak özgüveni de gelişmektedir. Serra'nın annesinin babasından boşanmaya karar vermesi ile kahramanımız ilk büyük travmasını yaşar. Akabinde annesinin kendisine teklif edilen terfi ile İstanbul'a taşınma kararı Serra'nın hayatında bir dönüm noktası olur. 6 kitap boyunca Serra'nın yeni bir aile düzenine, yeni bir şehirde yeni bir okula alışma sürecine ve yeni arkadaşlar edinme konusunda yaşadığı sıkıntılara şahit oluruz. Üniversite okumak için tekrar Ankara’ya dönüp bir kız arkadaşıyla birlikte ev tutarak kendi ayakları üstünde durma çabaları, ilk aşkları, hayal kırıklıkları, mezuniyeti, iş hayatına başlaması ve nihayetinde hayalindeki erkek ile evlenmesi ile 6.kitap sona erer. Seri toplam 12 kitaptan oluşmaktadır ve Serra'nın evlenip anne olması ve genç kızlıktan kadınlığa giden yolculuğunda başına gelenleri konu edinen bir anlayışla raflarda yerini almıştır. Serra'nın hayatta yaşadığı tüm sorunlara rağmen asla büyük ve telafisi olmayan hatalar yapmadığı, tökezlemediği, annesinin öğütleri ve iç sesiyle birlikte yolunu çok kolay bulan örnek bir genç kız olduğu en dikkat çeken husus olarak vurgulanabilir. Hikâye birinci şahıs anlatıcı olarak Serra'nın tuttuğu günlükler şeklinde yazılmıştır.

\subsection{Alman edebiyatından seçilen eserlerin özeti}

Asıl adı Elisabeth olan ancak Lelle diye hitap edilen 15 yaşındaki kahramanımız, meslek sahibi olmasına ră̆men çalışmayan annesi, mali müşavir olan babası ve kendisinden 2 yaş büyük olan ablası Cotsch (Constanze) ile birlikte nezih sayılabilecek bir semtte yaşamaktadır. Lelle yeme bozukluğu

\footnotetext{
Adres | Address

İstanbul Medeniyet Üniversitesi, Eğitim Bilimleri Fakültesi, Türkçe İstanbul Medeniyet University, Faculty of Education Sciences, ve Sosyal Bilimler Eğitimi Bölümü, Türkce Eğitimi ABD Cevizli Turkish and Social Scinces Education, Turkish Language Teaching Kampüsü, Kartal-İstanbul/TÜRKIYE $\quad$ Education, Cevizli Campus, Kartal-İstanbul /TURKEY e-posta: editor@rumelide.com 1 e-mail: editor@rumelide.com
} 

juvenile female literature / N. Cengiz. (pp. 608-632)

nedeniyle sürekli baygınlı geçiren çok zayıf bir karakterdir. Anoreksiya hastasıdır ancak kitapta hastalı̆̆ın adı ifade edilmez, sadece yeme bozukluğu şeklinde yer alır. Cinsellik, alkol, sigara gibi deneyimlere açık ve meraklıdır. Yemek yemeyi redetmesini de kişisel bir başkaldırı olarak açıklamaktadır. Ablası Cotsch güzelliği ve dişiliği ile okulda ve mahallede dikkatleri üzerine çeken, sık sık sinir krizleri geçiren, dik başlı ve cinsel dürtülerini her koşulda özgürce yaşayan ve 40'lı yaşlarındaki dul komşularıyla olan birlikteliğinden hamile kalan bir karakterdir. Anne karakteri edilgen ve özgüveni düşük kimlikle karşımıza çıkmaktadır. Karısı tarafından duygusal olarak engelli şeklinde ifade edilen baba karakteri ise ailesiyle duygusal olarak bir bağı olmayan, onların sorunlarıyla meşgul olmaktansa sürekli evin alt katındaki kilere çekilerek ayakkabılarını boyamak gibi hobilerinin peşinden giden bir figür olarak karşımıza çıkmaktadır.

\section{Analiz}

\subsection{Lelle serisinde aile}

Lelle hikâyenin başında 15 yaşındadır ve 6 kitap iki yıllık bir süreyi anlatır. Karakterimiz aslında ailedeki en mantıklı insan olarak karşımıza çıkmaktadır. Tüm aile üyelerinin birbirleri ile sorunları vardır ve olayların çoğu çatışmalara gebedir ancak Lelle hepsi arasında bir iletişim uzmanı olarak çabalamaktadır. Lelle'nin en büyük sorunu yeme bozukluğudur. Bulimia hastalığının eşiğindedir ve bir süreliğine bu sebeple bir klinikte bulunmak zorunda kahır. Hikâyenin başında Lelle yemek yemeyi kendi iradesi ile reddettiğini ve bunun ideolojik bir yaklaşım olduğunu ifade eder. Kendi vücudu üzerindeki özerkliğini korumak için herhangi bir dayatmaya boyun eğmeyeceğini belirtir. Cinsellik konusunda oldukça meraklı ve istekli bir genç kız olarak sağlını koruyucu önlemler alarak bu tür deneyimleri yaşamaktan çekinmez. Ablasının yaşantısını ve tavırlarını tasvip etmemekle birlikte gerekli durumlarda her zaman ona destek olur. Annenin acizliği karşısında yine onu anlayan ve dinleyen bir karakterdir. Babasıyla fazla ilişkisi yoktur.

Anne, zaman zaman aile şirketinde de çalışan aşırı endişeli bir ev kadınıdır. Baba tarafından daha önce fiziksel şiddet gördüğü bilinir ve duygusal şiddet son kitabın ortalarına kadar devam eder. Kendi sorunlarıyla baş etmekte zorlanan anne, çok sevdiği kızları ile çoğunlukla rahat bir ilişki içindedir. Kızları, annelerini aşırı endişeli tavırları sebebiyle rahatsız edici bulurlar. Lelle, annesinin davranışlarını "psikolojik tecavüz" olarak algıladığını belirtir. Bunaldığında veya bir sorun karşısında işin içinden çıkamadığı durumlarda bayılma ya da kalp krizi geçirme taklidi yapar. Arkadaşı ve komşusu olan Rita'yla tüm aile sırlarını paylaşır. Lelle ve Cotsch, annelerinin Rita ile eşcinsel bir ilişkisi olduğunu bile düşünürler ve Rita'dan nefret ederler. Sorunların üstesinden gelemediği durumlarda ara sıra kendini bir kadeh kanyak ile teselli eder. Aldatıldığını öğrendiği son kitabın ortalarından itibaren kabuğunu kırıp bambaşka bir kimliğe bürünen anne öncelikle kocasından ayrılmak ister. Kılık ve kıyafetini değiştirir ve kızının kendisinden 20 yaş küçük bir arkadaşı ile aşk yaşamaya başlar.

Mali müşavir olan babanın 6.kitabın ortalarına kadar karısıyla ve kızlarıyla herhangi bir duygusal bağının olmadığı görülür. Kızlarını sürekli sorun çıkaran birer engel olarak gördüğü anlaşılır, karısından mümkün olduğu kadar uzak durarak kendine kurduğu küçük dünyasında mutlu olmaya çalışır. Evdeki eşyalarla daha ilgili olduğu ifade edilir. Çocukları daha küçükken eşine fiziksel şiddet uyguladığı kitapta belirtilir. Özellikle eşine psikolojik şiddet uyguladığı anlaşılmaktadır. Akşam yemeğindeki bir aksaklık veya eksiklik kendisi için ciddi bir sorundur. Duyarsız, ilgisiz ve sevgisiz bir

Adres 
baba figüründen bahsedilebilir. Hikâyenin sonuna doğru eşini aldattı̆̆g ortaya çıkar ancak ailesini kaybetme korkusuyla karşılaşınca bambaşka bir insana dönüşür. Ailesine sahip çıkmaya çalışır.

Hikâyenin başında 17 yaşında olan Cotsch, okulda ve yaşadıkları mahallede güzelliği ve özgürce yaşadığı cinsel hayatı ile tanınmaktadır. 18 yaşından sonra mahallelerindeki evli erkeklerle dahi ilişkiye girmekten çekinmez. Babasına karşı büyük bir nefret duymaktadır. Okulda oldukça başarılı ve hırslı, özgüveni çok yüksek ve kariyer planlaması yapan bir karakterdir. Hamile kalıp çocuğunu doğurur ve harika bir anne olarak hem eğitimine devam eder hem modellik yaparak kendini ekonomik özgürlügünü sağlar.

\subsection{Serra serisinde aile}

Serra anlatımın başında 15 yaşında, dış görünüşüne pek önem vermeyen, biraz kilolu, sivilceli ve dikkat çekmeyen bir genç kızdır. Teyzesinin Çeşmedeki yazlığında geçirdiği yaz tatili Serra'nın fiziksel değişimin başlaması ve özgüveninin de paralel bir şekilde yükselmesi ile önem kazanır. Kadın olma sürecinde yaşıtı olan kuzeni Sırma'nın etkisi büyüktür. Annesi ile İstanbul'a taşındıktan sonra yeni bir düzen kurma konusunda birtakım sıkıntılar yaşar. Babasıyla ilişkisi mesafelidir. Baba figürünün zayıf kalması nedeniyle Serra hayali bir baba kurgulamıştır, Bill Cosby onun hayali babasıdır ve sıkıntılı zamanlarında rüyasına girerek kendisine öğütler verir. Serra, baba ilgisinin eksikliğini bu şekilde telafi eder. En büyük derdi arkadaşsız kalmak olan Serra bir dizi hatadan sonra kendi yolunu bulmayı başarır. Kişiliğinden taviz vererek arkadaş edinmenin yanlış olduğunu kavrar. Liseyi bitirir, gelecek kaygısıyla hedefler belirler, kararını oluşturmak için stajlar yapar, turizm okumaya karar verir, üniversiteden mezun olur, kolayca iş bulur, hayatı boyunca toplumsal normlara uygun davranışlar sergiler. Hayattaki en büyük destekçisi annesidir. Anne figürü Serra'ya her zaman doğru yolu bulmasında kılavuzluk yapar, örnek olur. Anne kusursuz bir anne olarak dikkat çeker. Serra 6 kitap boyunca 3 ilişki yaşar ve 3 . sevgilisiyle evlenir.

Özgüveni oldukça yüksek, kendi ayakları üstünde durabilen, eşinin sorumsuz tavırları nedeniyle boşanmayı göze alan bankacı bir karakterdir. Kızının üzerinde kontrol sahibi olmakla birlikte zaman içerisinde kızına daha fazla özgürlük sunduğu görülür. Kızının tüm gençlik sorunlarına öğütleriyle, sohbetiyle yol gösterici olur. Hoş görüsü ile kızına her koşulda destek olur. Çocuklu ve boşanmış bir kadın olarak farklı bir şehre taşınmak, mesleki olarak yeni bir pozisyonda sorumluluk üstlenmek, evinin tüm eksiklerini gidermek bunları yaparken hem yaşlı annesi hem de ergenlikle bulunan kızı ile yakından ilgilenmek onu okuyucunun gözünde örnek bir anne karakteri yapar.

Ankara'da bir üniversitede akademisyen olan baba, anneye göre daha mesafeli bir karakterdir. Baba ve koca olarak sorumluluklarını aksatmaktadır. Daha kendi halinde, kendi dünyasında bir baba figürü olarak karşımıza çıkar.

Ankara'da yaşamayan babaanne bir taraftan oğlunun yuvası dağıldı diye üzülmektedir diğer taraftan da kocasının kusurlarını görmezden gelerek idare edip yuvasını kurtarmadığı için gelinini suçlamaktadır. Torunu Serra’ya sevgiyle bağlıdır ve tek isteği ölmeden önce onun mutlu bir yuva kurduğunu görmektir. Geleneklere bağlı bir kadındır.

Anneanne ve Dede İstanbul'da yaşayan, görmüş geçirmiş ve yaşlarına rağmen modern sayılabilecek anlayışlı karakterlerdir. Her ikisi de yüksek sosyoekonomik sınıfta yer almaktadırlar ve Serra'ya gerek yaşam öğütleri gerek kuralları bağlamında kılavuzluk etmektedirler.

\footnotetext{
Adres $\mid$ Address

İstanbul Medeniyet Üniversitesi, Eğitim Bilimleri Fakültesi, Türkçe ve Sosyal Bilimler Eğitimi Bölümü, Türkçe Eğitimi ABD Cevizli $\quad$ Turkish and Social Scinces Education, Turkish Language Teaching Kampüsü, Kartal-İstanbul/TÜRKIYE $\quad$ Education, Cevizli Campus, Kartal-İstanbul /TURKEY e-posta: editor@rumelide.com $\mid$ e-mail: editor@rumelide.com
} 
Analysis of the protagonist's quest for identity within the context of family, friendship, love and sexuality in German and Turkish juvenile female literature / N. Cengiz. (pp. 608-632)

Teyze ve enişte İzmir'de yaşamaktadırlar ve Çeşme'de yazlıkları vardır. Serra'nın yaz tatillerini geçirdiği aile büyükleri arasında yerlerini alırlar. Teyze ev kadınıdır, eniştenin ise kendi şirketi olduğunu anlamaktayız. Sosyoekonomik olarak üst sınıfta yer alan çiftin Sırma isminde Serra ile yaşıt bir de kızları vardır.

Sırma, Serra'nın kuzenidir. Ailesiyle birlikte kışları İzmir'de, yazları ise Çeşme'de yaşamaktadır. Sırma'nın aksine süsüne pek düşkün, bakımlı ve alımlı bir kızdır. Serra genç kızlıktan kadınlığa geçiş serüveninde birçok şeyi Sırma'dan öğrenir. Örneğin ilk ağdasını Sırma yapar, ilk makyajını, yeni saç kesimini Sırma’ya borçludur.

Lelle serisinde bireysel kültürlere uygun olarak çekirdek aile göze çarparken, Serra serisinde ise kolektivist toplumlarda daha yaygın olarak karşımıza çımakta olan geniş aile kavramı dikkat çekmektedir. Lelle'de anne-baba gibi birincil otoritelerin bile kızlarının hayatlarında söz hakları bulunmazken, Serra'nın hayatına tüm aile üyeleri karışabilmektedir. Buradan yola çıkarak Almanca eserlerde bireyselci toplum özelliğinden ve düşük güç mesafesinden bahsetmek mümkündür Türkçe eserlerde ise kolektivist toplum özelliği ve yüksek güç mesafesi belirginlik gösterir.

\subsection{Arkadaşlık ilişkileri}

Lelle'nin çok fazla arkadaşı bulunmamaktadır. En yakın arkadaşı Alina problemli bir genç kızdır ve serinin son kitabında intihar eder. Alina dışında bağ kurarak arkadaşlık yaptığı bir kız arkadaşı yoktur Lelle'nin. Yalnız kalmayı ya da sevgilileriyle vakit geçirmeyi tercih eder.

Serra'nın Ankara'da başlayan hikâyesinde en yakın arkadaşı olan Ayşegül ile dostluğu yıllar boyu sürer. İstanbul'a taşınma fikri Serra'yı en çok arkadaşlarından ayıracağı için tedirgin eder. Taşındıkları yeni şehirde Serra arkadaş edinme çabasıyla birçok kez yanlış yollara sapar. Burada en çok dikkat çeken nokta, Serra'yı yanlış yollara sürükleyen sözde arkadaşların hepsinin birer anti kahraman olması ve davranışları toplum tarafından onaylanmayan türden davranışlar sergilemesidir. Serra arkadaş edinme gayreti ile kişiliğinden ve değer yargılarından tavizler vererek tökezler ve annesinin de öğütleri ile aklını başına alarak yeniden doğru yolu bulur. Hatalarından ders çıararak daha sonra yeni sınıfında oldukça fazla arkadaş edinen Serra bu arkadaşlarıyla ilişkilerini ömür boyu sürdürür.

Kahramanların arkadaş ilişkilerinden yola çıarak Lelle'nin oldukça bireyselci toplum kategorisinde yer aldığını ancak Serra'nın tipik bir kolektif toplum örneği teşkil ettiğini söylemek mümkündür.

\subsection{Aşk ve cinsellik}

Lelle ilk kitabın birinci sahnesinde kilden bir penis yaptığını ifade eder. Kendi bekaretini kendisi almak istemektedir. Duygusal bir olay olarak düşündüğü ilk cinsel deneyiminde acı hissederek olayın büyüsünü bozmak istemez. Bu giriş okura Lelle'nin cinsel hayatı ile ilgili ip ucu vermektedir. Lelle ilk ciddi ilişkisini anne ve babası ölmüş olan Arthur ile yaşar. Arthur sosyal bir sorumluluk projesi kapsamında Afrika'ya gidip ne zaman döneceği belli olmayınca Lelle duygusal açığını kapatmak için başka bir sevgili bulur ve henüz 15 yaşında ilk cinsel deneyimini de yaşar. Farklı sevgilileri ile cinsel birliktelikler yaşadıktan sonra geri dönen sevgilisi Arthur ile yollarına devam ederken aktif olarak cinsel yaşamını sürdürür. Kadın hastalıkları uzmanına da 15 yaşında ilk muayenesini olur ve doğum kontrol hapları kullanmaya başlar. Romanlarda asıl dikkat çekici nokta ablası Cotsch'un cinsel hayatıdır. Ailesi evdeyken kendi odasında, mahallerinde bir arabanın içinde, babasının ofisinde ve

Adres

İstanbul Medeniyet Üniversitesi, Eğitim Bilimleri Fakültesi, Türkçe ve Sosyal Bilimler Eğitimi Bölümü, Türkçe Eğitimi ABD Cevizli Kampüsü, Kartal-İstanbul/TÜRKIYE e-posta: editor@rumelide.com
Address

Istanbul Medeniyet University, Faculty of Education Sciences,

Turkish and Social Scinces Education, Turkish Language Teaching

Education, Cevizli Campus, Kartal-İstanbul /TURKEY

e-mail: editor@rumelide.com 
daha birçok yerde onlarca erkekle cinsel birliktelik yaşar. En son, komşuları olan 40’lı yaşlarında boşanmış bir erkek olan komşuları ile yaşadığı birliktelikten hamile kalır, bebeğini doğurur ve evlenir.

Serra'nın ilk aşkı 15 yaşında sınıfından bir çocuğa karşı hissettiği platonik duygulardır. İlk sevgilisi yine 15 yaşındayken yaz tatilini geçirmek için gittiği Çeşme'de kuzeninin bir arkadaşı olan Cüneyt’tir. Farklı şehirlerde de olsalar telefon ve mektuplarla bir süre ilişkilerini sürdürürler. Ancak Cüneyt ikinci ylla yaklaşırken mesafenin aşka engel olduğu nedeniyle Serra'yı aldatır ve başka bir kızla çımaya başlar. Serra daha sonra üniversitede Oktay ile tanışır ve üniversite bittiğinde nişanlanır, evlilik hazırlıkları esnasında doğru kişi olmadığına kanaat getirerek Oktay'dan ayrılır. Babaannesinin tanıştırdığı uygun damat adayı ile henüz Oktay ile birlikteyken dostane bir arkadaşlıkları başlar, Serra Oktay'dan ayrıldıktan sonra Özgür ile aralarında duygusal bir çekim başlar ve 6. kitabın sonunda bu ilişki evliliğe gider. Serra ilk aşkı olan Cüneyt ile 15 yaşın vermiş olduğu heyecanla sadece el ele tutuşur ve bir iki kez yanaktan bir öpücük sahnesi dikkat çeker. Bunların dışında asla daha fazla bir yakınlaşma olmaz. Üniversitede, oldukça özgür bir ortamda birliktelik yaşadığı Oktay ile yine asla toplum tarafından kabul gören, sınırları aşan bir yakınlaşma kitapta yer almaz. 20'li yaşlarında olmalarına rağmen herhangi bir cinsel yakınlaşmanın iması dahi yapılmaz.

Buradan hareketle, Lelle'nin genç bir kadın olarak ele alındığı eserlerde serbestliğin hüküm sürdüğü bir toplumdan bahsetmek mümkündür. Serra'da ise kahramanın cinsel isteklerine otokontrol uygulaması ile kısıtlayıcı toplum örneği kurguda dikkatleri çekmektedir.

Yukarıda ifade edilen kültürel boyutlar, eserlerde tespit edilen örnekler üzerinden daha ayrıntılı olarak ele alınacaktır. Bu bağlamda ilk örnekler güç mesafesinin yüksek olduğu durumların tespiti üzerinden yapilacaktır.

\subsection{Kültürel boyut örnekleri}

\subsubsection{Lelle serisi kültürel boyut örnekleri}

\section{Güç mesafesi yüksek}

Lelle serisinde yüksek güç mesafersine işaret eden bulgulara fazla rastlanmamıştır. En belirgin örnek annenin çocuklar henüz küçükken kocası tarafından şiddete maruz kalması olarak ifade edilebilir.

" [Einmal hat er Mama eine gescheuert. Da waren Cotsch und ich noch sehr klein.] [Papa ist ins Wohnzimmer gerannt, hat sich Mama gegrabscht und auf sie eingehauen. Mama hat gerufen: "Nein Berni! Bitte nein. Bitte nein! "Papa hat Mama losgelassen und weiter den Rasen gemäht] "(Ich habe einfach Glück. S. 244)

[Anneme bir kez bir tane patlatmıştı. Cotsch ve ben o zamanlar çok küçüktük.] [Babam oturma odasına koştu, annemi yakaladı ve ona vurmaya başladı. Annem seslendi: "Hayır Berni! Lütfen hayır. Lütfen hayır!” Babam annemi bıraktı ve çimleri biçmeye devam etti] ${ }^{4}$

\section{Güç mesafesi düşük}

İncelenen 6 kitap boyunca en fazla örneğe rastlanılan boyutlardan biri düşük güç mesafesidir. Aşağıdaki örnekte Cotsch annesi ile bir tartışmanın içindedir.

„[Mach die Tür auf. Sei nicht böse. Es tut mir Leid! “

4 Bu çalışmadaki örnek alıntıların çevirisi tarafıma aittir.

\footnotetext{
Adres $\mid$ Address

İstanbul Medeniyet Üniversitesi, Eğitim Bilimleri Fakültesi, Türkçe İstanbul Medeniyet University, Faculty of Education Sciences, ve Sosyal Bilimler Eğitimi Bölümü, Türkce Eğitimi ABD Cevizli Turkish and Social Scinces Education, Turkish Language Teaching Kampüsü, Kartal-İstanbul/TÜRKIYE $\quad$ Education, Cevizli Campus, Kartal-İstanbul /TURKEY e-posta: editor@rumelide.com 1 e-mail: editor@rumelide.com
} 
Analysis of the protagonist's quest for identity within the context of family, friendship, love and sexuality in German and Turkish juvenile female literature / N. Cengiz. (pp. 608-632)

„Ich hasse dich! “

„Bitte mach die Tür auf, dann können wir reden! “

„Ich will nicht mit dir reden. Ich will mit niemandem reden. Ihr kotzt mich alle an! “

„Komm wieder raus. Wir machen es uns in der Küche gemütlich! “

„Scheiß gemütlich! Mach's dir doch mit deiner Rita gemütlich. Mit der fummelst du doch eh schon rum! "] "(Ich habe einfach Glück. S. 27)

"[Kapıyı aç. Lütfen bana kızma. Üzgünüm!"

"Senden nefret ediyorum!"

"Lütfen kapıyı aç, konuşalım!"

"Seninle konuşmak istemiyorum. Ben kimseyle konuşmak istemiyorum. Hepiniz midemi bulandiriyorsunuz! "

Lütfen dışarı çık. Mutfakta rahat rahat konuşabiliriz! "

"Sıçtırma rahatlığına! Sen git Rita'yla rahat et. Zaten onunla bir haltlar karıştırmıyor musun! "]"

Cotsch babası hakkında görüş beyan ediyor.

„[,Antoine war meine große Liebe und das konnte Papa nicht ertragen. Das Arschloch hat mein Leben zerstört!"]“ (Ich habe einfach Glück. S. 125)

"["Antoine benim en büyük aşkımdı ve babam buna dayanamadı. Pislik hayatımı mahvetti!"]"

„[,„Und Papa?“

„Der pennt!“

„Arschloch!“

„Cotsch, hör auf!“

„Ist doch wahr. Papa ist echt ein Arschloch!“

„Cotsch bitte!“

„Immer soll ich aufhören. Kann Arthur doch ruhig wissen, dass Papa ein Arschloch ist. Papa ist ein Arschloch!“

„Na gut!“

„Arschloch, Arschloch, Arschloch!“]““ (Ich habe einfach Glück. S. 166)

"["Peki babam?"

"O uyuyor!"

"Pislik!"

"Cotsch, yapma!"

"Yalan mı? Babam gerçekten bir pislik! "

"Cotsch lütfen!"

"Her zaman beni susturmaya çalışıyorsun. Arthur'un, babamın bir pislik olduğunu bilmeye hakkı var. Babam tam bir pislik! "

"Tamam!"

"Pislik, pislik, pislik!"]

\section{Bireysellik}

Bireysellik boyutu da en sık karşlaşılan boyut olarak dikkat çekmektedir. Özellikle gençlerin kendi hayatları üzerinde karar verme yetkinliği olarak birçok bağlamda örneklerine rastlanmaktadır. Giyim kuşam tercihleri, sigara ve alkol tüketimi, boş zaman aktiviteleri, cinsellik gibi konularda genç kızlar

\footnotetext{
Adres $\mid$ Address

İstanbul Medeniyet Üniversitesi, Eğitim Bilimleri Fakültesi, Türkçe İstanbul Medeniyet University, Faculty of Education Sciences,

ve Sosyal Bilimler Eğitimi Bölümü, Türkce Eğitimi ABD Cevizli Turkish and Social Scinces Education, Turkish Language Teaching

Kampüsü, Kartal-İstanbul/TÜRKIYE $\quad$ Education, Cevizli Campus, Kartal-İstanbul /TURKEY

e-posta: editor@rumelide.com 1 e-mail: editor@rumelide.com
} 
büyüklerinden izin veya onay alma zorunluluğu hissetmezler. Aileler ancak belli durumlarda öneride bulunabilirler. Dayatmalar söz konusu olamaz.

„ [Musst du so viel rauchen, Lelle?] “(Ich habe einfach Glück. S. 91)

"[Bu kadar sigara içmek zorunda mısın Lelle?]"

15 yaşındaki Lelle’nin evden ayrılıp babasının iş yerindeki boş odada yaşamasına izin veriliyor.

„ [Leute, ratet mal, wo ich neuerdings wohne! Im Hinterzimmer von Papas Geschäft. Tatsächlich!]

"(Erste Liebe. S. 7)

"[Hey millet, artık nerede yaşadığımı tahmin edin! Babamın iş yerinin arka odasında. Gerçekten!]"

Evlilik kararlarını genç kızlar kimseye danışmadan onay almadan veriyorlar, sadece aileye alınan karar aileyebildiriliyor.

„ [Hiermit möchte ich um die Hand von eurer Tochter Constanze anhalten. Wir haben beschlossen zu heiraten. "] "(Leute, mein Herz glüht. S. 31)

"[Sizden kızınız Constanze'yi istiyorum. Biz evlenmeye karar verdik."]"

\section{Kolektivizm}

Lelle serisinde bu boyutta çok fazla örneğe rastlanamamıştır, tespit edilenler de annenin kızı Cotsch hakkındaki düşüncelerinden ibarettir.

"[und in der Nachbarschaft behaupten alle, meine Schwester sei eine Ehebrecherin oder ein „leichtes Mädchen “. Ihr ist es egal, Mama nicht.] “(Leute, mein Herz glüht. S. 20)

"[Ve mahalledeki herkes kız kardeşimin yuva yıkan biri olduğunu ya da 'kolay kz' olduğunu söylüyor. O, Cotsch umursamıyor ama annem umursuyor.] "

„[Die (Cotsch) hatte schon mit jedem was. Selbst mit unserem vierzigjährigen Nachbarn Helmuth, der deswegen die dritte Scheidung am Laufen hat. Seit der Geschichte mit ihm und Cotsch traut sich Mama kaum noch vor die Tür. Sie meint, meine Schwester hätte Schande über uns gebracht und alle Nachbarn würden sie schief angucken.]“ (Leute, ich fühle mich leicht. S. 8)

"[Cotsch șimdiye kadar herkesle bir șeyler yaşad. Üçüncü boşanma sürecini sürdüren kırk yaşındaki komşumuz Helmuth ile bile. Onunla ve Cotsch ile olan hikayeden beri, annem dışarı çıkmaya pek cesaret edemiyor. Kız kardeşimin yüzümüzü öne eğdiğini ve tüm komşuların ona ters ters bakacağını söylüyor.] "

\section{Serbest/kisıtlayıcı}

Lelle serisinde en çarpıcı özgürlükçü toplum örnekleri cinselliğin açık ve alenen yaşanması konusunda rastlanıyor. Ayrıca cinsellik hakkında konuşmak tabu sayılmamaktadır.

„[Auf alle Fälle stehe ich an diesem verregneten Sonntagnachmittag in meinem Zimmer am Fenster und töpfere mir aus Mamas Ton einen Penis. Der Penis ist ziemlich dick, weil ich viel Ton mit hochgenommen habe. „Wenn schon, dann richtig! “denke ich.]“ (Ich habe einfach Glück. S. 10)

"[Her halükârda, bu yağmurlu pazar günü, odamda pencerenin yanında duruyorum ve annemin kilinden bir penis yapıyorum. Penis oldukça kalın çünkü çok fazla kil almışım. "Madem böyle bir işe giriştim, o zaman doğru düzgün yapalım, öyle değil mi?] "

" [Ich will, dass mein getöpferter Penis fertig wird. Ich habe nämlich einen Entschluss gefasst: Ich will mich selbst entjungfern. So eine Entjungferung tut bestimmt weh, und da ist es besser, man hat es erledigt, bevor man sich mit einem Jungen ins Bett legt, der einen auch noch lieben soll.] "(Ich habe einfach Glück. S. 12)

\footnotetext{
Adres $\mid$ Address

İstanbul Medeniyet Üniversitesi, Eğitim Bilimleri Fakültesi, Türkçe İstanbul Medeniyet University, Faculty of Education Sciences, ve Sosyal Bilimler Eğitimi Bölümü, Türkçe Eğitimi ABD Cevizli $\quad$ Turkish and Social Scinces Education, Turkish Language Teaching Kampüsü, Kartal-İstanbul/TÜRKIYE $\quad$ Education, Cevizli Campus, Kartal-İstanbul /TURKEY e-posta: editor@rumelide.com 1 e-mail: editor@rumelide.com
} 
Analysis of the protagonist's quest for identity within the context of family, friendship, love and sexuality in German and Turkish juvenile female literature / N. Cengiz. (pp. 608-632)

"[Kilden kendim yaptığım penisimin bitmesini istiyorum. Bir karar verdim çünkü: Bekaretimi kendim bozmak istiyorum. Böyle şey mutlaka acıtıyordur ve en iyisi bu işi bir çocukla yatağa girmeden önce bu işi halletmektir, yoksa olayın duygusal olmasını beklemek zor.] "

, [Mama ist näher rangegangen und hat Cotsch hinter den vernebelten Scheiben erkannt. Die lag halbnackt auf dem zurückgekurbelten Beifahrersitz und Rainer mit der Hasenscharte hing über ihr. Mama hat zaghaft an die Scheibe geklopft und gemeint:

„Cotsch, wenn ihr fertig seid, kommst du doch rein, ja? “

Cotsch hat sich mächtig bespitzelt gefühlt. Sie hat angeschrien:

„Hau ab du Sau! "] “(Ich habe einfach Glück. S. 112)

“[Annem biraz daha yaklaştı ve buğulu pencerelerin arkasındaki Cotsch'u tanıdı. Geriye yatırılmış yan koltukta yarı çıplak vaziyetteydi ve tavşan dudaklı Rainer onun üzerine abanmıştı. Annem çekinerek cama vurdu ve dedi ki:

"Cotsch, bitirdiğinizde içeri gireceksin, değil mi? "

Cotsch gözetlendiğini hissetti ve bağırmaya başladı:

"Defol git seni pislik!"] "

„ [Wir sitzen auf Marcels Matratze, mit dem Rücken an der Wand, trinken Bier, rauchen Zigaretten, Joe Cocker singt.] [Und ich hoffe echt, dass Marcel mal ein paar Anstalten macht, sich mir zu nähern.] ... [Jetzt gäbe es die Möglichkeit, sich zu küssen. Und es ist affig, dass wir es nicht tun. Der Moment ist günstig, wir sind alleine, aber Marcel machts nichts.] ... "(Erste Liebe. S. 83, 84)

"[Marcel'in yatağında oturuyoruz, sırtımız duvara yaslanmış vaziyette bira içiyoruz ve sigara, Joe Cocker şarkı söylüyor.] [Ve gerçekten Marcel'in bana yaklaşmak için birkaç adım atmasını umuyorum.] ... [Şu an bunu yapmıyor olmamız o kadar aptalca ki. Şu an tam zamanı, evde yalnızız ama Marcel harekete geçmiyor.] ..."

Bu kitap serisinde cinselliğin, alkol ve sigara kullanımın herhangi bir baskıya veya otokontrole maruz kalmadan yaşanması üzerine birçok örnek sıralamak mümkündür.

\subsubsection{Serra serisi kültürel boyut örnekleri}

\section{Güç mesafesi yüksek}

Güç mesafesi yüksek olan toplumlarda genç kızlardan büyüklerine ev işlerinde yardımcı olmaları ve büyüklerine hizmet etmeleri arzu edilen bir davranış olarak karşımıza çıkmaktadır. Eserde de davranış biçimine verilebilecek birçok örnek mevcuttur. Bunlardan bir tanesi eserde şu şekilde yer almaktadır.

“[Eve dönerken de bir güzel azar işittim. Büyükler iş yaparken ben öylece yerimde oturuyormuşum]

[Yerimden kalkmaya neredeyse kira istiyormuşum, oysa hemen firlayıp yardım etmeliymişim]

[Saygısız bir genç kız görüntüsü sergiliyormuşum (Sözler aynı anneme ait)]” (BGKGD 1. S.4)

15-16 yaşlarındaki Serra sıradan etkinliklere gidebilmek için bile annesinden izin almak zorundadır ve çocuğun ailesinin kim olduğu da yine kolektivist toplum göstergesi olarak önemlidir.

“[„Anneciğim... önümüzdeki cumartesi günü bir arkadaşın partisi var. Gidebilirim değil mi? “]

„[,Dur bakalım, kimmiş bu arkadaş? “]”

"Adı Atasay. Bizim sınıftan bir çocuk."

"Kimin oğlu? "]” (BGKGD 1. S.12)

“[Aylin beni maça davet etti. Ve maç cumartesi günü. Gidebilirim değil mi, anne?”]" (BGKGD 2. S.139) 
Serra bir arkadaşının annesi ile konuşmasını yadırgar, söz konusu karakter eserde anti kahraman olarak yer almaktadır ve davranışları genel olarak olumsuz örnek teşkil etmektedir. Serra bu kızda kendisini rahatsız eden bir şeyler olduğunu hemen fark eder ancak ondan uzaklaşması biraz zaman alır.

„[Anne kızı ne diye kapıda tutuyorsun,” diye bağırdı, eh, ben annemle o ses tonundan konuşsam, neler olabileceğini düşünmek bile istemem]" (BGKGD 2. S.195)

Bir yüzme yarışması bile büyük sorunlara sebebiyet verebiliyor. Genel olarak romandaki genç kızların babaları ile ilgili düşünceleri aşağıdaki alıntılarda belirtilmiştir.

\begin{abstract}
„[Beni aceleye getirdin, apar topar, düşünmeden kabul ettik ama kızım, sen nasıl gideceksin, bu bir. İkincisi, nerede kalacaksın? Üçüncüsü de babanın haberi bile yok, dedi.] [“Anne, dedim." "Koca kızım, kendi başıma gidebilirim." "Haydi gittin diyelim, nerede kalacaksın?”]“ (BGKGD 1. S.85)
\end{abstract}

„[Baban niye kızdı Tümay?”

"Ondan izin almadan nasıl kendi başıma karar verirmişim. Ona sormadan kendi başıma işlere kalkışıyormuşum, madem öyleymiş, ne halim varsa göreymişim ve çat diye telefonu yüzüme kapattı." (BGKGD 1. S.87)

"[Yani en doğal şeyler için bile babamdan izin alırken korkuyorum. Oysa ben herhangi bir şey için, ister izin olsun, ister başka bir şey, korkmadan sorabilmeyi öyle isterdim ki.]” (BGKGD 1. S.88)

„[Ben de babamdan çekiniyorum. Bir şey yaptığı yok, dövmüyor, bağırmıyor ama ona yakın olamıyorum. Ya kızarsa, ya ters tepki gösterirse diye her şeyimi annemle hallediyorum.]“ (BGKGD 1. S.89)

\title{
Güç mesafesi düşük
}

Serra babasının kendisini pek umursamadığınu düşünür ve bu konuıyu annesiyle tartışırken odasına çekilip kapıyı çarpıyor olması düşük güç mesafesi kapsamında değerlendirilebilecek masum bir örnektir. İncelemelerde düşük güç mesafesini işaret eden çok az örneğe rastlanılmıştır ve örneklerin hemen hepsi yine toplum tarafından kabul gören olumlu uca yakın bireysellik örneklerdir.

\author{
" [Nefret ediyorum ondan, sen de tutmuş, yalan söyledin diyorsun, "diyerek içimi döktükten sonra \\ kalkıp odama koştum. Kapımı da bir güzel çarptım.] „, (BGKGD 1. S.198) \\ "[Annemle aydınlık mutfağımızda keyifli bir kahvaltı yaptık.] [rahat rahat konuşup \\ tartışıyoruz, tıpkı iki arkadaş gibi.]” (BGKGD 2. S.278)
}

„[Bunun üzerine bizimkiler, 'Íyice düşündüğüne göre biz senin kararına saygılııı, bu senin hayatın. Bizim için önemli olan senin mutluluğundur' dediler.]” (BGKGD 3. S.9)

\section{Bireysellik}

İncelenen tüm romanlarda kılavuz görevi gören anne, Serra'ya boşanma nedenini anlatırken hem bireyselliğini vurgular hem de Serra'nın kimlik arayışında ona ışık tutmaya çalışır. Bireysellik vurgusu roman boyunca ağırlıklı olarak annenin öğütlerinde kendini gösterir.

„[Ben yıllardır gerçekten var olmayan bir aile düzenini varmış gibi göstermekten yorulmuştum artık. Buraya kadar gelebildim, bundan sonrası hepimiz için zararlı olacaktı. Babanla birbirimizi kırmaya başlayacaktık, hoş son zamanlarda buna başlamıştık bile.]” [Şimdiyse herkes kendi yolunda. O da kötü bir insan değil, eh," dedi, güldü. "Ben de kendimi kötü bir insan olarak görmüyorum ama kişiliklerimiz uyuşmuyor. Ayrı ayrı tipte insanlarız.] [babama yürekten teşekkür ediyorum] ["Ĕ̆er o beni okutmasaydı, ısrarla yönlendirip meslek sahibi yapmasaydı, bugün bu

\footnotetext{
Adres $\mid$ Address

İstanbul Medeniyet Üniversitesi, Eğitim Bilimleri Fakültesi, Türkçe ve Sosyal Bilimler Eğitimi Bölümü, Türkçe Eğitimi ABD Cevizli $\quad$ Turkish and Social Scinces Education, Turkish Language Teaching Kampüsü, Kartal-İstanbul/TÜRKIYE Education, Cevizli Campus, Kartal-İstanbul /TURKEY e-posta: editor@rumelide.com 1 e-mail: editor@rumelide.com
} 
Analysis of the protagonist's quest for identity within the context of family, friendship, love and sexuality in German and Turkish juvenile female literature / N. Cengiz. (pp. 608-632)

boşanmayı gerçekleştiremezdim. Bunca yıldan sonra bir çocukla baba evine sığınmak, o kadar kolay değil.”

Gözlerini bana dikerek, "İşte onun için annen olarak birincil ve en önemli görevimin, seni okutup, bir meslek sahibi yapmak olduğuna inanıyorum. Hiç kimseye muhtaç olmadan, iki ayağının üstünde dimdik durabilen bir kadın olmanı sağlamak benim şu andaki en büyük amacım."]" (BGKGD 1. S.231, 232)

„[Sen tek başına da olsan, yine aynı değerdeki Serra'sın. Serra olmak için arkadaş desteğine ihtiyacın yok. Ama işte deneyimsizliğin nedeniyle, arkadaşın olmazsa sanki sen de var olamazmışsın şeklinde düşünüyorsun. Tek yanlışın bu," Kendine inanmak zorundasın. Aksi halde hayat boyu sana el uzatacak birilerini beklersin."]” (BGKGD 2. S.239, 240)

„[Aslını istersen, size ev tutulması başlı başına bir eğitim oldu, yalnız başınıza pek çok şeyle başetmeyi öğrendiniz.]" (BGKGD 4. S.171)

„[O yaşlar geride kaldı. Olsa olsa sana fikir verebilir, değişik yollar gösterebilir ve o yollarda neler olabileceğini, tahminlerimi ortaya koyabilirim, sonrada, eğer istersen, karşılıklı tartışabiliriz.]" (BGKGD 4. S.185)

\section{Kolektivizm}

Kolektivizme işaret eden onlarca örnekten özellikle aile ve arkadaşlık ile ilgili olanların seçılmesine özen gösterilmiştir. Örneklerin büyük çoğunluğu, bireylerin kendi istek ve arzularını düşünerek hareket etmeleri değil, toplumun dayatmaları sonucu yerleşmiş algıların ne derece etkili olduğunu göstermektedir.

"[Annemle babam boşanacaklarmış!] [Okuldakilere ne diyeceğim? Arkadaşlarımın yüzüne nasıl bakacağım? Bana acıyarak "zavallı" diyecekler]" (BGKGD 1. S.21)

“[Artık bir aile gibi değildik. Bölünmüş̧, birbirimize yabancılaşmıştık sanki]” (BGKGD 1. S.128)

(Babaabbem),,[Gel benim zavallı yavrum,” diyerek kapı eşiğinde beni öpmeye koyuldu.] ... „[Görüyor musun başımıza gelenleri...vah, vah, vah... hiç olacak iş mi bu... Bizim ailede ilk kez bu boşanma işi başımıza geliyor...vah, vah, vah," diye bir ileri bir geri sallanarak, dizlerini ovuşturmaya başlamaz mı..."Her evde, her ailede neler olur ama insan idare ediverir. Çocukların hatırı için, düzen bozulmasın diye," dedi]” (BGKGD 1. S.171)

„[Başarın için gerçekten mutluyum ama ben ne olacağım? Benim hayatım ne olacak? Okulum, arkadaşlarım ne olacak?]“ (BGKGD 2. S.3)

“[yeni bir okul, yeni arkadaşlar fikri hiç de hoşuma gitmiyor. Ben Ayşegül'le Yeşim gibi arkadaşları bir daha nerede bulurum]" (BGKGD 1. S.23)

„[Babaannene uğramayı sakın unutma, yoksa alınır ve darılır,” diye bir kez daha uyardığından, bu işin kurtuluşu yoktu.]“ (BGKGD 1. S.170)

„[Dedemle anneannem pazar günleri mutlaka bir yerlere giderler. Tabii artık bizi de bu gezmelere dahil ediyorlar.]“ (BGKGD 2. S.167)

„[Şimdi onlar bize destek oluyorlar, daha sonraki yıllarda da biz anneannemle dedeme yardımcı olacağız.]” (BGKGD 2. S.118)

„[Tatilim çok güzel geçti. Evimde, yuvamda, annem, anneannem, dedemle yüreğimdeki sevgi pınarını yeniden doldurdum.]" (BGKGD 4. S.198)

„[Onunla çıkmayacağım, çünkü henüz yeterince olgun değil. Şu aralar çıktı̆̆ı kızlar onun için bir anlam taşımıyorlar, ama hevesini alması, eğlenmesi gerek] [bütün kızlar Bora gibi biriyle çıkmak için dünden razlar] [Bense onlardan biri olmamalıyım] [Bora benim tam evlenmek istediğim erkek.]" (BGKGD 2. S.42)

\section{Serbestlik/kısıtlama}

Serra'nın 19 yaşında ilk dudaktan öpücüğü anlatılıyor.

Adres

İstanbul Medeniyet Üniversitesi, Eğitim Bilimleri Fakültesi, Türkce ve Sosyal Bilimler Eğitimi Bölümü, Türkçe Eğitimi ABD Cevizli Kampüsü, Kartal-İstanbul/TÜRKIYY e-posta: editor@rumelide.com
Address

İstanbul Medeniyet University, Faculty of Education Sciences,

Turkish and Social Scinces Education, Turkish Language Teaching

Education, Cevizli Campus, Kartal-İstanbul /TURKEY

e-mail: editor@rumelide.com 
„[Ah Serra”, derken bana öyle bir bakışı vardı ki, yine o dayanılmaz çekimi tüm gücüyle hissettim. Bana doğru eğildi] [Yüzü yüzüme o kadar yakındı ki] [Artık kaçacak gücüm yoktu. Ve beni öptü!]' (BGKGD 4. S. 323)

„[Gecenin sonunda Oktay beni eve getirdi, ama kapının önünde oyalanıp duruyor, yüzüme, saçlarıma, dudaklarıma öpücükler konduruyordu.

"Oktay, sokak ortasında biraz ayıp olmuyor mu," deyince," Sen artık benim nişanlımsın," diyor, öpmeye devam ediyordu.]” (BGKGD 5. S.486)

6 kitabın içinde en açık saçık sahne, Özgür’ün yıllar sonra Serra'ya aşkını itiraf etme şeklidir. Cinsellik olarak bile tanımlanamayacak aşağıdaki alıntı yazarın en sansürsüz aşk sahnesi olarak dikkat çekmektedir.

\begin{abstract}
„[Öpüşüyorduk, hem de yıllardır birbirimize hasret kalmışçasına öpüşüyorduk. Elleri saçlarımın arasindaydl.

"Serra," diye fisıldadı kulağıma." Seni öyle seviyorum ki.]" [Tutulmuş gibiydim. Ben ben değildim sanki] [Yine öpüşüyorduk. Sonra sessizlik.]” (BGKGD 6. S.529)

„[Ona doğru uzandım. Kollarımı boynuna doladım. Ve onu öptüm, işte cevabım dercesine.]” (BGKGD 6. S.541)
\end{abstract}

Serra toplumsal normları içselleştirmiş bir genç kız olarak gecenin bir vakti annesine gelen telefon hakkında bulunduğu yargı oldukça düşündürücüdür.

\begin{abstract}
„[Bir telefon] „[Derya?” Üstelik bu bir erkek sesiydi! Öyle şaşırdım ki, olduğum yerde kalakaldım. Ne cevap, ne bir şey! Kimdi anneme Derya diyebilecek kadar yakın bu adam] [ Üstelik gecenin bu saatinde.]" (BGKGD 5. S.96)
\end{abstract}

15 yaşındaki Serra'nın ilk aşkı Cüneyt ile birlikteyken aslında tüm gençlerin ortak heyecanlarını paylaşması ancak otokontrol uygulayarak duygularının alevlenmesini önlemesine dair örnekler aşağıda yer almaktadır.

\begin{abstract}
„[Tam eşikte sular birikmişti. Cüneyt beni belimden kavrayarak eşiği atlattı. Onun elini belimde hissedince kalbim küt küt atmaya başladı. Nasıl anlatayım, çok tatlı bir duygu. Sonra elimden tuttu ve birlikte içeri girdik."] [Çok teşekkürler Haydar Ağabey," dedi Cüneyt ve yine beni elimden tuttu] [(şunu itiraf etmeliyim ki, bu son kez elimi uzattığında, ben de elimi ona uzattım). Elimi tutması hoşuma gidiyordu, yüreğim yine o tatlı hoplamayı yapmıştı. Bana neler oluyordu bilmiyorum ama çok hoş bir şeyler olduğu kesin!] [Ihlamurlarımızı içerken konuşmaya başladık.]" (BGKGD 1. S.114, 115)

„[Bahçede Cüneyt'le ilk kez doğru dürüst göz göze geldik. Onca insanın arasında ona bakarsam sanki duygularım yüzümde kocaman harfler şeklinde yanıp sönmeye başlayacak gibi geliyordu.]" (BGKGD 3. S.6)

„[Birden, nasıl olduysa ayağım yaşlı bir çamın köküne takıldı] [Cüneyt hemen beni belimden tuttu. Bir an öylece kaldık, ona hiç bu kadar yakın olmamıştım. Bütün vücudum elektriklenmişti sanki, kalbim delicesine çarpıyordu. Daha önce hiç hissetmediğim duygular içindeydim. Şimdiye dek duyumsamadığım bir güç tüm benliğimi esir almış gibiydi. Karmaşık duygular içindeydim. Çok zevkli ama bir o kadar da ürkütücüydü. Cüneyt'in gözlerine bakmamaya çalışarak kollarının arasından yavaşça sıyrıldım.]" (BGKGD 3. S.54)
\end{abstract}

\title{
6. Sonuç-tartışma
}

\subsection{Lelle’nin kimlik arayışı}

Kahramanımız 15 yaşındaki Lelle, aslında sorumluluk sahibi bir karakterdir. Her zaman herkesi memnun etmek ister ve her zaman her şeyi doğru yapmaya çalışır. Lelle kendisi de hayatındaki amacını, "hiç kimse tarafından azar işitmemek için her şeyi doğru yapmak" şeklinde ifade eder.

\footnotetext{
Adres $\mid$ Address

İstanbul Medeniyet Üniversitesi, Eğitim Bilimleri Fakültesi, Türkçe İstanbul Medeniyet University, Faculty of Education Sciences,

ve Sosyal Bilimler Eğitimi Bölümü, Türkce Eğitimi ABD Cevizli Turkish and Social Scinces Education, Turkish Language Teaching

Kampüsü, Kartal-İstanbul/TÜRKIYE $\quad$ Education, Cevizli Campus, Kartal-İstanbul /TURKEY

e-posta: editor@rumelide.com 1 e-mail: editor@rumelide.com
} 
Analysis of the protagonist's quest for identity within the context of family, friendship, love and sexuality in German and Turkish juvenile female literature / N. Cengiz. (pp. 608-632)

İnsanların tepkisini çekmekten korktuğunu ifade ettiği aşağıdaki alıntı Lelle’nin karakter çözümlemesinde önemli bir ip ucu olarak değerlendirilebilir.

\begin{abstract}
„[Das liegt daran, dass ich von Mama gelernt habe, sogar meine Gegenspieler in ihrem Verhalten zu verstehen und zu akzeptieren.]" (Erste Liebe S.54)

"[Bunun nedeni, annemden rakiplerimin davranışlarını bile anlamayı ve kabul etmeyi öğrendiğim içindir.]"
\end{abstract}

Aile içi bağların sıkıntılı olması ver her an bir olayın krize dönüşmesi, Lelle'nin bu duruşunu bir savunma mekanizması olarak geliştirmiş olması muhtemel gözükmektedir. Bu yaklaşım Lelle'yi aslında çok fazla yoran, kendi kişiliğini oturtma konusunda engel teşkil eden bir yaklaşımdır. Çünkü sürekli edilgen ve esnek davranmak zorundadır. Yemek yemeyi reddetme duruşu da kendi iradesi ile yapabildiği tek eylem olduğu için aslında tekpisel bir dışavurum olarak algılanabilir. Baba maddi ve manevi olarak ailesine destek olmak konusunda sıkıntılı bir karakteridr. Çocukların her türlü sıkıntısı ile anne ilgilenmek zorunda kalır ve bu durum kendisini tüketir. Lelle yorgun, ilgiye ve sevilmeye muhtaç annesine bir yerde annelik yapmaktadır. Lelle'nin kimlik arayışında kendini bulmakta zorluk yaşaması aile sorunlarından kaynaklanmaktadır. Annesinden gördüğü koşulsuz sevgi ise Lelle'yi en çok anneye bağlamaktadır.

Sanatçı olmak istediğini, ve çocukluk travmalarının bunun için biçilmiş kaftan olacağını düşünür. Çocuklukta ne kadar çok travma yaşanırsa, bir sanatçı olarak sonraki yaşamında o kadar iyi olacağı görüşünü savunur. Yolunu bulamamış varoluşları sever. Bu dünyada hayatta kalmak için deli olmak gerektiğini ve sorununun tam da buradan kaynaklandığını düşünür çünkü kendisinin deli olmadığını ifade eder. Bu yüzden kendini çok yalnız ve yanlış anlaşılmış hisseder ve Anoreksiya'ya sığınır. Yemek yemeyi reddederek aynı zamanda kendi kendini imha etmek ve kendi kaderini tayin etmek ister. Açlı̆̆ını bastırmak için sigaraya tutunur ve sıkı bir sigara içicisi olur. Tedavisi için birkaç aylığına klinikte bulunduğu süre, Lelle'nin hayatında bir dönüm noktasır. Orada ölümle karşılaşır ve doğru yolu bulmak için her şeyden önce kendisini sevmek zorunda olduğunu fark eder. Annesine duyduğu sevgi onu bir yerde yeniden hayata bağlar. Kendi iradesiyle yeniden yemek yemeye başlama kararı alır.

Lelle'nin kimlik arayışında hayatı doya doya yaşamak, yeni tecrübeler edinmek oldukça önemlidir. Aydınlanmak için kişinin yaşam sürecinde tüm acı gerçekleri tatması gerektiğini savunur. Bir çok insanın hayatını bitkisel hayat olarak tanımlar. Karakterimiz 68 kuşağına hayranık duyar, dar görüşlü topluma karşı yürütülen özgürlük mücadelesini, o dönemdeki insanların yaşam hedeflerinin sanatla uğraşmak, müzik dinlemek, sevişmek ve aşık olmak olduğunu ve bu hedeflerin gayet makul hedefler olduğunu düşünür. Kadınların özgürleşme mücadelesinin de bu yıllara tekabül etmesi de ayrıca önem teşkil eder Lelle için. Kendi ailesindeki cinsiyet eşitsizliğini annesinin pısırıklığına bağlar ve asla böyle bir yetişkin olmak istemediğini ifade eder. Lelle'nin ailesindeki olumsuzluklar aslında kendi yolunu bulmasında oldukça büyük bir öneme sahiptir. Bu sayede Lelle ne istemediği sorularına yanıtlar bulur. Çok sevdiği erkek arkadaşı Arthur'dan ayrılma sebebi yine genç bir kadın olarak kendi değerinin farkında oluşu ve annesinin yolundan gitmek istemeyişinden kaynaklanmaktadır. Arthur ilişkilerine Lelle'den farklı anlamlar yüklemektedir ve Lelle onun sürekli farklı ülkelerde olmasını kabullenemez. O halde en doğrusu yolları ayırmak ve kendi yolunda devam etmektir.

Lelle'nin en yakın arkadaşı olan Alina'nın intiharı Lelle'nin hayatında ikinci bir dönüm noktasıdır. Alina eserlerde çok dikkat çeken bir anti kahraman olarak dikkat çekmektedir. Biseksüel olan Alina, sürekli siyah kıyafetler giyinip siyah makyaj yapan, kurukafalı takılar ve tişörtler seven, siyaha boyadığı saçlarını spray ile dikleştiren, ünlü müzik grubu "Tokio-Hotel” hayranı olarak oldukça dikkat

\footnotetext{
Adres $\mid$ Address

İstanbul Medeniyet Üniversitesi, Eğitim Bilimleri Fakültesi, Türkçe İstanbul Medeniyet University, Faculty of Education Sciences, ve Sosyal Bilimler Eğitimi Bölümü, Türkce Eğitimi ABD Cevizli Turkish and Social Scinces Education, Turkish Language Teaching Kampüsü, Kartal-İstanbul/TÜRKIYE $\quad$ Education, Cevizli Campus, Kartal-İstanbul /TURKEY e-posta: editor@rumelide.com 1 e-mail: editor@rumelide.com
} 
çeken bir karakterdir. Alina'nın ailesi ise aksina güç mesafresi oldukça yüksek ve gerekli gördükleri durumlarda çocuklarına şiddet uygulamaktan çekinmeyen ebeveynlerdir. Alina örneği üzerinden empati yoksunluğunun nelere sebebiyet verebileceği anlatılmaya çalışllmıştır. Sorunlarıyla baş edemeyen ve kendini yalnız hisseden gençler Alina üzerinden anlatılır.

Alina’nın ölümü Lelle’yi derinden etkiler ve kimlik arayışında mutlu bir yaşamın amacı nedir sorusuyla önemli bir dönüm noktasına ulaşır. Lelle bu soruya cevap ararken, öncelikle kim olduğunu, ne istediğini ve nereye ait olduğunu bilmesi gerektiğini düşünür. En büyük eksiklerinin koşulsuz sevgi, güven ve koruma olduğunu anlar. Tüm sorunların üstesinden ise, kendini severek gelebileceğini idrak eder ve öz saygısı bu şekilde başlar. Asıl mutluğun ne olduğunu aşağıdaki alıntıdan anlıyoruz.

„ [Ich liebe meine Leute. Ich brauche sie. Hier bei ihnen bin ich zu Hause. Durch sie bin ich ein Teil von ihnen. Was habe ich nur für ein Glück!] “(Leute, die Liebe schockt. S. 188)

"[Hayatımdaki insanları seviyorum. Onlara ihtiyacım var. Burası benim yurdum, evim. Ben onların bir parçasıyım. Ne kadar şanslıyım!]

$\mathrm{Bu}$ alıntı, karakterin kimlik arayışındaki en önemli faktörün aile ve aidiyet olduğu sonucunu ortaya koymaktadır. Kahramanımız Lelle'nin öncelikle kendisine sunulan özgür ortam sayesinde yeni deneyimler yaşaması, hatalar yapması, tökezlemesi, çaresiz hissetmesi, duvarlara toslaması gerekir, çünkü birey hatalarından öğrenir ve kendisi için en doğru olan şeyin ne olduğunu ancak deneyimleyerek, yaşayarak öğrenebilir. Ancak günün sonunda kendini güvende hissettiği, sevgi alabildiği bir ailenin varlığı bu yolda kahramanımıza güç vermektedir. Lelle'yi daha yakından ele aldığımızda, farkındalığı yüksek, sorumluluk sahibi ve entelektüel bir birey olarak ifade edebiliriz.

\subsection{Serra'nın kimlik arayışı}

Kahramanımız Serra Noyan, hikâyenin başında ideal gibi görünen bir dünyada yaşamaktadır. Noyan ailesi sosyoekonomik olarak ortanın üstünde, entelektüel ve elit diyebileceğimiz bir sınıfa mensuptur. Serra’nın başlarda kendisini daha çocuk olarak gördüğünü en basitinden, klyafet seçiminden anlayabilmekteyiz. Bir mağazanın vitrininde görüp beğendiği açlk mavi pantolon, pembe tişört ve yine açık mavi renkteki ceket kahramanımızın çocuksu ve naif karakterine vurgu yapmaktadır. Henüz hiç siyah kıyafet giymemiş olduğunu, anneannesinin kendisine almış olduğu siyah kazağa şaşırması ve annesinin buna müsaade edip etmeyeceğini sorgulaması ile de dikkat çeken bir husustur. Yetişkinler siyah kıyafet giymektedir ve Serra henüz bir çocuktur. Teyzesinin kendisine vermiş olduğu dergilerden resimler keserek anket defterine yapıştırması da yine çocuksu ve naif karakterine vurgu olarak dikkat çekmektedir. İlk ağda deneyimi de yine 15 yaşında kuzeni Sırma'nın yardımı ile öğrenebildiği bir şeydir. Serra'nın kendini henüz çocuk gibi gördüğü aşağıdaki alıntısı verilen Sırma ile arasında geçen bir diyalogdan da anlaşılmaktadır.

„[Yoo olmaz Serra," dedi yine o bilgiç haliyle. "Bir kadın kendine bakmalı."

“İyi ama biz kadın değiliz ki, bunu annelerimiz düşünsün.]” (BGKGD 1. S.28)

Serra, annesiyle çok iyi anlaşır. Annesi modern, öz saygısı gelişmiş ve ekonomik özgürlüğü olan bir kadındır. Onunla neredeyse her şey hakkında konuşabilir. İlk başta sorunları hakkında açıça konuşmakta zorlanır ama zamanla bu durum değişir ve anne-kız ilişkileri sorunsuz ilerler. Serra'nın özellikle babasıyla sorunları vardır. Babasının kendisini görmediğini, fark etmediğini ve dinlemediğini hisseder. Herhangi bir kısıtlama olmaksızın sohbet edebileceği, güvende hissettiği bir babaya özlem duyar. Bu özlemini de bilinçaltında Bill Cosby ile kurduğu ilişkisi ile gidermektedir. Serra’nın ve tüm

\footnotetext{
Adres $\mid$ Address

İstanbul Medeniyet Üniversitesi, Eğitim Bilimleri Fakültesi, Türkçe İstanbul Medeniyet University, Faculty of Education Sciences, ve Sosyal Bilimler Eğitimi Bölümü, Türkce Eğitimi ABD Cevizli Turkish and Social Scinces Education, Turkish Language Teaching Kampüsü, Kartal-İstanbul/TÜRKIYE $\quad$ Education, Cevizli Campus, Kartal-İstanbul /TURKEY e-posta: editor@rumelide.com 1 e-mail: editor@rumelide.com
} 
Analysis of the protagonist's quest for identity within the context of family, friendship, love and sexuality in German and Turkish juvenile female literature / N. Cengiz. (pp. 608-632)

arkadaşlarının kimlik arayışlarında gelecek kaygısının ve meslek seçiminin çok öncelikli bir yere sahip olduğu söylenebilir. Her konuda farklındalığı olan süper kahraman Serra mutlu bir hayatın altın anahtarı olan doğru mesleği seçebilmek için henüz ortaokul ve lise dönemlerinde bu konu hakkında ciddi araştırmalar yapmaktadır. Meslekler hakkında kaynaklar araştırır, stajlar yapar ve kendisine en uygun sektörün turizm olduğuna kanaat getirir. Ancak seçmek istediği sektör aile büyükleri tarafından pek hoş karşılanmaz, çünkü hizmet sektörü güç mesafesi yüksek toplumlarda makbul ve seçkin kabul edilmez, ancak Serra kendi fikrinden taviz vermez ve turizm okur.

Serra'nın kimlik arayışı çok inişli ve çıkışlı bir yolculuk değildir. Gerçek hayatta karşılaşılması pek mümkün olmayacak şekilde Serra yaşamış olduğu deneyimler sayesinde her zaman en doğru yolu bulur ve asla içinden çlkılmaz durumlara düşecek hatalar yapmaz. Ona yolculuğunda ışık tutan bir takım otorite figürleri vardır. Güç mesafesi yüksek toplumlarda sıklıkla karşılaşılan örnek davranış gösteren ve toplumda saygın kabul edilen kişilerdir bunlar. Serra'ya kimliğini güvenli bir zemine oturtma konusunda öncelikle annesi, daha sonra lise öğretmeni Mualla hanım ve üniversitede söyleşilerine katıldığı Doğanay hoca rehberlik ederler. Estetik değerler, sanat, adabı muaşaret gibi konularda her zaman bir otorite figürü Serra'ya yol gösterir. Her şeyin dozunda olması gerektiği vurgusu da yine bu öğretilerde yer alır. Örneğin dedesinden alkol tüketiminin hangi ölçüde olması gerektiğini ve kadın erkek ilişkileri hakkında çok aydınlatıcı bilgiler edinir ve hayatı boyunca bu öğrendiklerine uygun davranışlar sergiler. İlk cinsel deneyimlerin de tercihen evlendikten sonra yaşanması gerektiği ile ilgili bilgileri hem Serra hem de okurlar, Serra'nın annesi ile yapmış olduğu uzun ve derin sohbetten çıkarmaktadırlar. Serra gerçekte var olması mümkün olmayan mükemmelikte bir genç kızdır. Her Türk ailesinin arzuladığı bir kahramandır. Ufak tefek hataları ona ders olur ve asla kendini zor durumlara sokmaz. Her zaman etrafında yolunu aydınlatan ve kendisine çözümleri rengarenk haplar şeklinde gümüş tepsilerde sunan yardımcıları vardır. İpek Ongun, 5. kitabın önsözünde, bu seri aracılığıyla gençliğin kişisel gelişimini hedeflediğini ve gençliğin sorunları üzerine çalıştığını ifade etmiştir (Ongun,2016).

Lelle ve Serra'nın kimlik arayışlarında karşılaştıkları sorunlar içinde yaşadıkları toplumun hoşgörüsü çerçevesinde ele alınmıştır. Alman toplumunda bireysellik boyutu ağır basan bir anlayış hüküm sürdüğü için gençler de birer birey olarak kabul görmekte ve kendi kaderlerini tayin haklarına sahip kabul edilmektedirler. Lelle bu bağlamda toplumu hiçbir şekilde dikkate almadan hareket edebilme imkanına sahipken Serra'nın örnek teşkil etmesi açısından toplum odaklı bir yaklaşım gösterme zorunluluğu vardır. Her ne kadar ergenlik evrensel bir olgu ise ve bu süreçteki hislerin, dürtülerin, arzuların ve keşfetme isteğinin farklı toplumlardaki gençlerde benzerlikler gösterse de, her birey içinde bulunduğu toplumun değerlerine göre otokontrol uygulamayı öğrenmektedir. Serra bu durumun en belirgin temsilcilerinden biri olarak ifade edilebilir.

Tüm bu bilgiler ışığında Bir Genç Kızın Gizli Defteri serisiyle oldukça didaktik bir amaç gütmüş olan Ongun'un olay örgüsü bu eğitici işlevin gölgesinde gerçeklikten uzak gelişmiştir. Okur adeta kişisel gelişim romanı okuduğunu hissetmektedir. Ongun'un eserlerinde göze çarpan bir diğer husus ise, "terbiyeli" kızların, yani toplumsal normlara uygun davranan genç kızların her zaman ön plana çıkarılmasıdır. Toplumsal normlara aykırı davranan genç kızlar birer anti kahraman olarak ibretlik olay örgüleriyle olumsuz davranış sergileyen ve toplumda dışlanan ve sevilmeyen kişiler olarak hikâyede yerlerini almaktadırlar. Ongun, genç kız edebiyatını bir yol gösterici olarak düşünerek, okurlarının psikolojik ve fizyolojik ihtiyaçlarını çok gerçekçi bir bakış açısıyla ve çağın gereklerine uygun şekilde değerlendirmeden 100 yıl önceki genç kızların anlayışları ve beklentileri doğrultusunda ele almıştır. Ancak ülkemizde genç kızların büyük bir çoğunluğunun Ongun'un eserlerini büyük bir

Adres

İstanbul Medeniyet Üniversitesi, Eğitim Bilimleri Fakültesi, Türkçe ve Sosyal Bilimler Eğitimi Bölümü, Türkçe Eğitimi ABD Cevizli Kampüsü, Kartal-İstanbul/TÜRKIYE e-posta: editor@rumelide.com
Address

Istanbul Medeniyet University, Faculty of Education Sciences,

Turkish and Social Scinces Education, Turkish Language Teaching

Education, Cevizli Campus, Kartal-İstanbul /TURKEY

e-mail: editor@rumelide.com 
zevkle ve tutkuyla okudukları da gözlemlenmektedir. Bu bağlamda, Lelle serisinin Türkçe çevirisinin gençler arasında aynı şevkle okunup okunmayacağı ve hatta ergenlik dönemindeki bir bireyin iç dünyasının bu denli ortaya serildiği, cinselliği bu denli özgürce yaşandı̆̆ edebiyatı kapsamında Türk okuruna ulaşma olasılığını merak etmekteyim.

İncelenen eserlerden hareketle, Türk genç kız romanları arasında ayrı bir yeri olan "Bir Genç Kızın Gizli Defteri” serisini, ülkemizdeki genel anlayış bağlamında genelleyerek, bu tür eserlerin amacının ve işlevinin okurlarına doğru yolu göstermek olduğunu, okuruna toplumsal düzene başarılı bir entegrasyon sağlayabilmek için ışık tuttuğunu ve Almanya'da gençlik edebiyatı ödülü almış bir eserin de yine bu bağlamda genelleme yapılarak amacının ve işlevinin okurlarına toplumsal düzene başarılı bir entegrasyon sağlayabilme konusunda ışık tutmak olmadığını, aksine okuruyla empati kurmak, hatalarına rağmen yanında olduğunu yalnız olmadı̆̆ını hissettirmek ve okurların kendi hayatlarında hissettiklerinin çok doğal bir sürecin parçası olduğunu aktarmak açısından empati kurma işlevi olduğu ifade edilebilir.

\section{Kaynakça}

Cengiz, N. (2018) Die kulturbezogene Problematik in der Adoleszenz in türkischen und deutschen Jugendromanen anhand der Werke von Ipek Ongun und Alexa Hennig von Lange. Hacettepe Üniversitesi. Ankara.

Gansel, C. (2004): Adoleszenz und Adoleszenzroman als Gegenstand literaturwissenschaftlicher Forschung (Forschungsbericht). In: Zeitschrift für Germanistik. Heft 1/2004, Neue Folge, XIV. Jg., S. 130-149.

Asutay, H. (2005) Gençlik Yazınbilimi Açısından Alman Genç Kız Romanlarının Gelişimi. Trakya Üniversitesi Sosyal Bilimler Dergisi Cilt:6 Sayı:1 Haziran

Kaulen, H. (1999). "Jugend- und Adoleszenzromane zwischen Moderne und Postmoderne", 1000 und 1 Buch Heft 1, S. 4-12

Kırtıl, G. (2012). Edebi Metinlerin Sosyolojik İmkânı Üzerine Farklı Yaklaşımlar, Adıyaman Üniversitesi Sosyal Bilimler Enstitüsü Dergisi. ISSN: 1308-9196. Yıl: 5 Sayı: 10

Köppe, T. / Winko, S. (2013). Neuere Literaturtheorien Eine Einführung Stuttgart: Weimar. Verlag J. B. Metzler

Lange. A.H von. (2002). Ich habe einfach Glück. Hamburg: Rogner\&Bernhard\&co

Lange. A.H von. (2006). Erste Liebe. Hamburg: Rowohl Taschenbuch Verlag.

Lange. A.H von. (2008). Leute, ich fühle mich leicht. München: cbt/cbj Verlag.

Lange. A.H von. (2009). Leute mein Herz glüht. München: cbt/cbj Verlag.

Lange. A.H von. (2009). Leute, die Liebe schockt. München: cbt/cbj Verlag.

Lange. A.H von. (2010). Leute, das Leben schockt. München: cbt/cbj Verlag.

Moran, B., 1994b, Edebiyat Kuramları ve Eleştiri, Cem yay., İstanbul.

Moran, B., 2005. Edebiyat Kuramları ve Eleştiri. İstanbul. İletişim.

Neydim, N. (2005). Türkiye'de Çeviri ve Telif Eserlerde Genç Kız Edebiyatı. İstanbul: Bu.

Neydim, N. (2007). Genç Kız Edebiyatındaki Baba-Kız İlişkisine Yansıyan Gelenek ve İdeoloji. II. Ulusal Çocuk ve Gençlik Edebiyatı Sempozyumu-Ankara Üniversitesi Basımevi S:473-480

Neydim, N. (2014) Çeviri ve Telif Eserlerde Genç Kız Edebiyatı Türk Dili Dil ve Edebiyat Dergisi Cilt: CVII Sayı: 756 Aralık. Türk Dili Dil ve Edebiyat Dergisi, cilt. CVII, ss.1-8, 2014 (Hakemsiz Dergi)

Ongun, İ. (2015). Arkadaşlar Arasında BGKGD. Istanbul: Artemis.

\footnotetext{
\begin{tabular}{r|l} 
Adres & Address \\
İstanbul Medeniyet Üniversitesi, Eğitim Bilimleri Fakültesi, Türkçe & İstanbul Medeniyet University, Faculty of Education Sciences,
\end{tabular} ve Sosyal Bilimler Eğitimi Bölümü, Türkce Eğitimi ABD Cevizli $\quad$ Turkish and Social Scinces Education, Turkish Language Teaching Kampüsü, Kartal-İstanbul/TÜRKIYE $\quad$ Education, Cevizli Campus, Kartal-İstanbul /TURKEY e-posta: editor@rumelide.com 1 e-mail: editor@rumelide.com
} 
Analysis of the protagonist's quest for identity within the context of family, friendship, love and sexuality in German and Turkish juvenile female literature / N. Cengiz. (pp. 608-632)

Ongun, İ. (2015). Bir Genç Kızın Gizli Defteri. Istanbul: Artemis.

Ongun, İ. (2016). Adım Adım Hayata BGKGD. Istanbul: Artemis.

Ongun, İ. (2016). İşte Hayat BGKGD. Istanbul: Artemis.

Ongun, İ. (2016). Kendi Ayakları Üstünde BGKGD. Istanbul: Artemis.

Ongun, İ. (2016). Şimdi Düğ̈̈n Zamanı. Istanbul: Artemis.

Özgül, M. K. 2003, Kandille İskandil. Ankara: Hece.

Vogt, J. (2008). Einladung zur Literaturwissenschaft. Stuttgart: UTB Verlag

Wagner, M. (2005): Der Adoleszenzroman im Unterricht. München: Ludwig Maximilians-Universität München. Studienarbeit.: S.4

Wild, R. (2008). Geschichte der deutschen Kinder- und Jugendliteratur. Stuttgart: Verlag J. B. Metzler 